\title{
Composition of airway bacterial community correlates with chest HRCT in adults with bronchiectasis
}

DOI:

10.1111/resp.13653

\section{Document Version}

Accepted author manuscript

Link to publication record in Manchester Research Explorer

\section{Citation for published version (APA):}

O'neill, K., Einarsson, G. G., Rowan, S., Mcilreavey, L., Lee, A. J., Lawson, J., Lynch, T., Horsley, A., Bradley, J. M., Elborn, J. S., \& Tunney, M. M. (2019). Composition of airway bacterial community correlates with chest HRCT in adults with bronchiectasis. Respirology. https://doi.org/10.1111/resp.13653

\section{Published in:}

Respirology

\section{Citing this paper}

Please note that where the full-text provided on Manchester Research Explorer is the Author Accepted Manuscript or Proof version this may differ from the final Published version. If citing, it is advised that you check and use the publisher's definitive version.

\section{General rights}

Copyright and moral rights for the publications made accessible in the Research Explorer are retained by the authors and/or other copyright owners and it is a condition of accessing publications that users recognise and abide by the legal requirements associated with these rights.

\section{Takedown policy}

If you believe that this document breaches copyright please refer to the University of Manchester's Takedown Procedures [http://man.ac.uk/04Y6Bo] or contact uml.scholarlycommunications@manchester.ac.uk providing relevant details, so we can investigate your claim.

\section{OPEN ACCESS}


1 Title: The composition of the airway bacterial community correlates with chest HRCT

2 in adults with bronchiectasis

3 Katherine O'Neill $\mathrm{PhD}^{1}$,*

4 Gisli G Einarsson $\mathrm{PhD}^{1}$, ${ }^{\text {* }}$

5 Stephen Rowan²,

6 Leanne Mcllreavey ${ }^{3}$,

7 Andrew J. Lee $\mathrm{PhD}^{1}$,

8 John Lawson ${ }^{4}$,

9 Tom Lynch4,

10 Alex Horsley 5 ,

11 Judy. M. Bradley PhD',

12 J. Stuart Elborn ${ }^{1, * *}$

13 Michael M Tunney ${ }^{3}$,**

14

15 Wellcome-Wolfson Institute For Experimental Medicine, School of Medicine, Dentistry and 16 Biomedical Sciences, Queen's University Belfast, United Kingdom

17 2South Eastern Health and Social Care Trust, United Kingdom

18 3School of Pharmacy, Queen's University Belfast, United Kingdom

$19{ }^{4}$ Belfast Health and Social Care Trust, United Kingdom

20 5Division of Infection, Immunity \& Respiratory Medicine, University of Manchester, 21 Manchester, United Kingdom

22

23 *Joint first authors

$24 * *$ Joint senior authors

25 Corresponding author: Dr Katherine O'Neill, Wellcome-Wolfson Institute For Experimental 26 Medicine, School of Medicine, Dentistry and Biomedical Sciences, Queen's University Belfast.

27 k.oneill@qub.ac.uk

28 Word count abstract: $242 / 250$ 
Word count full text: $2909 / 2500$

30

\section{Summary at a Glance}

This study reports on the relationship between airway bacterial community composition as measured by high throughput sequencing of the $16 \mathrm{~S}$ rRNA marker-gene, chest HRCT and clinical measures in BE. The association between loss of diversity and chest HRCT severity suggests bacterial dominance with pathogenic bacteria may contribute to disease pathology.

37 Abstract

\section{Background}

In Bronchiectasis not caused by Cystic Fibrosis (BE), chronic, polymicrobial airway infection contributes to the underlying pathogenesis of disease. There is little information on whether bacterial community composition relates to clinical status.

\section{Objective}

To determine the relationship between bacterial community composition, chest high resolution computed tomography (HRCT) scores and clinical markers in BE.

\section{Methods}

A sub-group of $\mathrm{BE}$ patients from a previous cross-sectional study were analysed. Spontaneously expectorated sputum was analysed using culture-independent sequencing on the Roche 454-FLX platform covering the V1-V3 region of the 16S rRNA marker-gene. Chest HRCT scans, multiple breath washout, spirometry and blood inflammatory markers were collected. Pearson ( $r$ ) correlation coefficient was used to assess relationships.

\section{Results}

Data from 21 patients were analysed (mean [SD] age 64.0 [7.7]; female:male 14:7; mean [SD] $\mathrm{FEV}_{1} 76.5$ [17.2]). All bacterial community composition metrics (bacterial richness, diversity,

54 evenness, dominance) correlated with percentage BE score, with more severe HRCT abnormality relating to lower bacterial richness, evenness and diversity (range $r=-0.47$ to - 
57 with lower diversity and richness (range $r=-0.44$ to $-0.47 ; p<0.05$ ). Bacterial community 58 characteristics did not correlate with lung function.

59 Conclusion

60 This is the first study to indicate a relationship between bacterial community characteristics by 61 16S rRNA marker-gene sequencing, structural damage as determined by chest HRCT and 62 clinical measures in BE. The association between loss of diversity and chest HRCT severity 63 suggests bacterial dominance with pathogenic bacteria may contribute to disease pathology. 64

65 Key Words: bronchiectasis, bacterial community composition, airway microbiome, lung 66 function

67 Short title: Airway bacterial community and HRCT

68

69

70

71

72

73

74

75

76

77

78

79

80

81

82

83

84 


\section{Introduction}

Bronchiectasis (BE) not caused by cystic fibrosis (CF) is a debilitating illness with symptoms of recurrent cough, daily sputum production, recurrent chest infections, and poor healthrelated quality of life (HRQoL) $(1,2)$. Patients are frequently chronically infected with bacterial pathogens (3). Chronic and polymicrobial airway infection contributes to the underlying pathogenesis of the disease, with progressive lung damage resulting from recurrent bacterial infections and inflammatory responses (4). Traditional culture-based methods have identified Haemophilus influenzae, Pseudomonas aeruginosa and Streptococcus pneumoniae as commonly detected bacterial pathogens (1). The application of cultureindependent techniques has detected a much greater variety of microbes and can provide a more comprehensive description of the composition of the microbial community (5). A number of studies have investigated the microbial community composition in $\mathrm{BE}$, however there is less information on how community profiles relate to clinical outcomes in BE.

The aim of this study was to explore the relationship between bacterial community composition in sputum (bacterial richness, diversity, evenness and dominance), and chest high resolution computed tomography $(\mathrm{HRCT})$ scores, $\mathrm{FEV}_{1} \%$ predicted, $\mathrm{FEF}_{25-75} \%$ predicted, lung clearance index (LCl) and blood inflammatory markers (white cell count [WCC] and C-reactive protein [CRP]). We hypothesised that quantitative measurements from HRCT were related to bacterial diversity.

\section{Methods}

\section{Recruitment}

A sub-group of patients from a previously published study (conducted between September 2011 and September 2012) was analysed (6). In brief, adults with a radiological diagnosis of non-CF BE by HRCT were recruited from the regional BE clinic at Belfast City Hospital, Belfast Health and Social Care Trust. Patients were either non-smokers or ex-smokers. No current smokers were included. Sputum and blood sample were collected and spirometry and LCl measurements undertaken at a single visit, with a HRCT scan performed within 24 hours of 
each study visit. Full inclusion and exclusion criteria are provided in the supplementary appendix 1 . Written informed consent was obtained from all patients. The study was approved by the Office of Research Ethics Committee for Northern Ireland (ORECNI) reference: 10/ NIR03/44.

\section{Clinical data}

119 Demographic data (gender, age, smoking status), a full medical history (including the number 120 of pulmonary exacerbations requiring intravenous antibiotic treatment in the previous 12 121 months) and current medication was recorded.

\section{Sputum processing}

(i) Routine culture

Routine culture results from the patients most recent expectorated sputum sample, carried out by the Belfast Health and Social Care Trust (BHSCT) clinical microbiology laboratory, and the presence or absence of target pathogens was recorded. If no pathogens were detected but the clinical specimen grew normal commensal flora, a report was issued detailing "no significant growth". The status of $P$. aeruginosa infection as defined by the Leeds criteria (8). Routine culture for the BE patient population did not assess for non-tuberculosis mycobacterium NTM or fungi.

\section{(ii) Culture independent analysis}

134 During the scheduled study visit, a spontaneously expectorated sputum sample was collected. 135 Samples were observed for adequate volume (>200mg) and for samples containing a mixture 136 of sputum plugs and liquid phase, the sputum plugs were separated and used for all 137 downstream applications. Processing of sputum samples for culture-independent analysis; extraction of bacterial DNA, library preparation for sequencing on the Roche 454-FLX platform and processing of raw sequence output were conducted as previously described (5). After 
140 normalisation (via rarefaction), based on the sample with the fewest reads (1800), a total of 14137,800 reads were included in all downstream analysis.

HRCT

Inspiratory and expiratory HRCT scans of the chest were performed within 24 hours of the study visit, on a 64-slice CT scanner (Siemens AG, Munich, Germany) in the supine position. Two thoracic radiologists (JL, TL) reviewed each scan independently, using a standardized scoring method (9). This result gives a global CT score of BE and, in addition, scores each lobe on type of $\mathrm{BE}$, extent, mucus plugging, air trapping and emphysema. The complete scoring system can be seen in the supplementary appendix 2. A score for each lobe was recorded, which was then converted to a total score for each of the parameters assessed: total BE score, average bronchiectatic bronchus size, degree of mucus plugging, degree of peribronchial thickening, parenchymal score, and degree of air trapping (hyperinflation score). The higher the number in the scoring method, the more severe the abnormality. Scores were converted into a percent score for comparison.

\section{Spirometry}

Spirometry was performed during the study visit in accordance with American Thoracic

Society/European Respiratory Society guidelines on a MicroLab 3500 spirometer 160 (CareFusion, Basingstoke, UK) (10). Percent predicted values for $\mathrm{FEV}_{1}$ and $\mathrm{FEF}_{25-75}$ were calculated from the all age's reference data published by Stanojevic and colleagues (11).

A MBW test was performed during the study visit using the Innocor gas analyzer (Innovision A/S, Odense, Denmark), modified as previously described to use an open circuit wash-in protocol $(12,13)$. The MBW test was carried out before spirometry. During test, patients 167 performed tidal breathing in the seated position with a nose clip on. Three MBW trials were 
performed with the mean result of at least two acceptable trials recorded. A test was excluded

169 if functional residual capacity differed by more than $10 \%$ from the median of recordings or 170 there was evidence of a leak or irregular breathing pattern. Analysis of washout data was 171 performed with custom software (Simple Washout program).

\section{Blood inflammatory markers}

174 A blood sample was collected during the study visit and processed in the routine hospital 175 laboratory for WCC $\left(10^{9}\right.$ cells/L) and CRP (mg/L).

\section{Statistical analysis}

Statistical analysis was performed in SPSS (version 21 PASW Statistics 21; IBM, Armonk, NY), Prism (version 5.01; GraphPad Software Inc., La Jolla, CA) and in the R statistical environment using the vegan package (version 2.4-6) (14). Ecological indices for the bacterial of statistical packages are included in supplementary appendix 3. diversity index $[H]$, evenness $\left[e^{H / S}\right]$ and dominance $[D]$ were calculated for each sample. The relationship between clinical variables and ecological community indices were assessed using Pearson correlation coefficient and linear regression $(15,16)$. Difference between sub-groups were assessed using Kruskal Wallis test. A p value of $<0.05$ was considered significant. Details

\section{Results}

Twenty-one subjects from a cohort of 60 subjects (35\%) (study 2 in a project to assess whether the lung clearance index is a repeatable and more sensitive indicator of CT scan abnormalities than spirometry in BE; recruited between September 2011 and September 2012) provided a sputum sample and therefore had data available for analysis (6). Only $35 \%$ of subjects provided a sample during the study visit as they were also instructed to collect a 24 hour sputum samples (ahead of the study visit) and not always able to produce an additional fresh sample. 
197 There was a female predominance with the majority idiopathic in aetiology. The full subject characteristics of the 21 subjects are detailed in Table 1.

Using Roche 454-FLX sequencing of the V1V3 region of the 16S rRNA marker-gene, the most common organisms identified (top 10 primary taxa by total read number) included Haemophilus spp. (28.2\%), Streptococcus spp. (23.8\%), Veillonella spp. (6.7\%), Moraxella spp. (5.0\%), Corynebacterium spp. (4.1\%), Prevotella spp. (4.0\%), Pseudomonas spp. (3.8\%), Stenotrophomonas spp. (2.4\%), Unclassified family Gamellaceae (2.1\%) and Neisseria spp. $(2.0 \%)$. Further information on the relative abundance, defined as the proportion of taxa in each of the samples, is shown in Supplementary Table 2.

207

All metrics of bacterial community composition correlated with chest HRCT percentage bronchiectasis score (Table 2). The relationship indicated that the more severe the HRCT abnormality the lower the bacterial richness, evenness and diversity. The strongest correlations were seen between chest HRCT percent bronchiectasis score and the Shannon Wiener diversity index $(r=-0.66 ; p=0.001)$ and between the chest HRCT percent bronchiectasis score and dominance $(r=0.65 ; p=0.001)$ (supplementary figures $A-F)$.

There was a significant relationship between blood CRP and both the Shannon Wiener 216 diversity index $(r=-0.47 ; p=0.03)$ and dominance $(r=0.50 ; p=0.02)$ (Table 2 and supplementary 217 figure G). There was also a significant relationship between blood WCC and richness ( $r=-0.44$; $218 \mathrm{p}=0.04)$ (Table 2 and supplementary figure $\mathrm{H}$ ).

220 There was no relationship between any measure of bacterial community composition and $221 \mathrm{FEV}_{1}, \mathrm{FEF}_{25-75}$ or $\mathrm{LCl}$ (range $\mathrm{r}=0.01$ to $0.21 ; \mathrm{p}>0.05$ ) (Table 2 and supplementary figures I-K). 
222 On inspection of the relationship between the relative abundance (proportion of taxa in each 223 sample) of the top 10 primary taxa identified, and the HRCT and clinical measures, positive 224 relationships were seen between the abundance of recognised pathogens Haemophilus spp., 225 Stenotrophomonas spp. and Pseudomonas spp. and a number of clinical measures (i.e. 226 greater relative abundance correlated to a worse score in the clinical measure) (Table 3). 227 Conversely, negative relationships were seen between the abundance of anaerobic 228 organisms belonging to genus Veillonella and Prevotella and some clinical measures (i.e. 229 greater relative abundance correlated to a better score in the clinical measure).

230 Considering $P$. aeruginosa colonisation status as measured by routine laboratory culture 231 (never, intermittent, chronic colonisation), only $\operatorname{FEV}_{1}(p=0.04)$ and $\operatorname{LCl}(p=0.04)$ could 232 significantly discriminate between groups (never, intermittent and chronically colonised). None 233 of the chest HRCT markers (BE, airway thickening, mucus plugging, parenchymal, air trapping 234 and overall total score) showed a significant difference between these groups.

236 Eleven out of 21 subjects were taking oral antibiotics at the time of sampling (9/21 macrolides; $2372 / 21$ other oral antibiotics). There was a significant negative relationship between those taking 238 oral antibiotics and community richness $(r=-0.58 ; p=0.006)$ and Shannon Wiener diversity 239 index $(r=-0.44 ; p=0.047)$ indicating that those taking antibiotics were more likely to have less 240 bacterial community richness and diversity in the airway. There was no difference in any of 241 the ecological community measures in those taking inhaled antibiotics or inhaled 242 corticosteroids $(p>0.05)$.

\section{Discussion}

245 This is the first study to suggest a relationship between bacterial community characteristics as measured by $16 \mathrm{~S}$ rRNA marker-gene sequencing, structural abnormality as measured by chest HRCT and a range of clinical measures in patients with BE. In this study, we found that some bacterial community characteristics correlated with structural abnormalities as 
249

250

251

252

253

254

255

256

257

258

259

260

261

262

263

264

265

266

267

268

269

270

271

272

273

274

275

276

measured by total chest HRCT score, percentage BE, airway thickening and percentage parenchymal score, with a greater abnormality as measured by HRCT relating to a lower bacterial richness, evenness and diversity. The relationship between blood inflammatory markers, CRP and WCC, and some of the bacterial community composition markers support these findings, with greater inflammation relating to lower bacterial diversity. The relative abundance of some recognised pathogens showed positive relationships with some HRCT and clinical measures, whereas negative relationships were seen between the abundance of anaerobic organisms, HRCT and clinical measures. Such organisms have previously been associated with milder lung disease in CF (17). Results from this study in BE suggest a similar picture. However, overall bacterial community characteristics did not correlate with lung function.

We have previously demonstrated significant relationships between CT and LCI in BE, which we postulated reflected early lung changes before changes in $\mathrm{FEV}_{1}$ were observed (6). The relationships seen in this study between HRCT and bacterial community characteristics further add to the clinical picture, indicating that the microbiome may also be important to consider in the early detection of lung disease.

In this study, significant differences in lung function were seen only with regard to $P$. aeruginosa colonisation status as per routine laboratory culture. It is well established that chronic colonisation with $P$. aeruginosa is associated with poorer lung function in $\operatorname{BE}(18,19)$. It is less clear how the wider microbiome community composition impacts lung function in $\mathrm{BE}$. HRCT markers are the most sensitive modality in detecting lung disease, particularly changes early in the disease trajectory and/or small degrees of change. Changes in chest HRCT may be evident before lung volumes, flow (spirometry), gas mixing efficiency ( $\mathrm{LCl}$ ) and symptoms are apparent as has been shown in CF (20). Decreased bacterial diversity in this study was associated with changes detected by chest HRCT, indicating that a lack of diversity may be associated with more severe disease. Therefore, analysis of the airway microbiota in this study may provide a better understanding of the disease pathophysiology in BE. 
277 The relationship observed between greater severity of disease (as measured by HRCT) and 278 lower bacterial richness, evenness and diversity cannot imply causation in this study, and 279 there may be other contributors to disease processes in the airway that are not reflected in 280 the sputum microbiota such as the potential contribution of fungi and/or viruses. Furthermore, 281 the lack of available samples from healthy controls for comparison with samples from BE is a 282 potential limitation to the current study. Although our cohort consisted of individuals with mild 283 to moderate $\mathrm{BE}$, the omission of individuals without marked disease prevents determination 284 of whether people with BE were significantly different from healthy age-matched individuals. 285 However, in a previous study, we observed differences between individuals diagnosed with 286 mild to moderate COPD, smokers and healthy non-smokers, where both community diversity 287 and evenness were significantly lower in individuals with COPD when compared to both of the use and age (22-27).

291

The results from this study add to those reported by Rogers et al. 2013 who reported a relationship between bacterial diversity and inflammation (sputum neutrophil count) in 41 patients with BE. In contrast to our study, Rogers et al. did find that bacterial diversity was significantly positively correlated with $\mathrm{FEV}_{1}(28)$. The reason for the absence of a relationship between bacterial diversity and lung function in our study may be partly explained by the patient group characteristics. Patients in our study had a milder disease phenotype with a mean [SD] number of pulmonary exacerbations in the previous year 0.2 [0.5] compared with 5.0 [2.8] in the study by Rogers et al. Changes in lung function may have been less apparent in the present study. Furthermore, the smaller cohort studied $(n=21)$ may not have been large enough to show these relationships. In a prospective six-month study, Cox and colleagues examined samples from 85 subjects to assess the associations between bacterial diversity and clinical outcomes (24). In agreement with our findings, the authors found that the structure of the bacterial community related only weakly to underlying disease as measured by $\mathrm{FEV}_{1}$. 
305 Weak relationships between the microbiome composition and clinical status have also been

306

307

308

309

310

311

312

313

314

315

316

317 reported in CF by Zhao et al (27). A further possible explanation for the weak relationship observed between bacterial diversity and clinical outcomes in this study may be the complexity of disease processes which could impact the microbiome e.g. presence of co-morbidities, viral and fungal infections and antibiotic use, as well as the heterogeneity of the patient group. These factors may have introduced significant variability. This study included a number of different underlying aetiologies of $\mathrm{BE}$, which has been previously reported to account for some variance in bacterial communities (24). Sub-group analysis to stratify patients according to factors which likely impact significantly (disease aetiology, pulmonary exacerbation frequency, antibiotic use) was not appropriate in this small cohort, but is important in future larger studies. The importance of the predominant organism in relation to clinical status has been highlighted by Rogers et al. who found that $P$. aeruginosa and $H$. influenzae dominant communities were associated with poorer clinical outcomes, compared to other taxa dominated communities in BE (29). In this study, culture of $P$. aeruginosa was associated with poorer $\mathrm{FEV}_{1}$ and $\mathrm{LCl}$ but no other individual organism was associated with poorer outcomes.

The significant relationship observed in those patients taking oral antibiotics (macrolides and others) and some of the airway microbiota community characteristics is important to consider as other studies have highlighted antibiotic treatment to be a primary driver for changes in microbiota community structure in CF (30). The cross-sectional nature of the current study did not allow for the assessment of the response to antibiotic treatment following pulmonary exacerbations, which is the period where most significant changes in the airway microbiota occur. Our findings needs to be replicated in a larger group, including regression analysis to assess the contribution of potential confounding factors in predicting microbiota community structure in BE patients.

The small sample size is a clear limitation and the analysis performed was exploratory. Replication of these correlation analyses and subsequent findings in a larger sample is 
333 required with sub-group study analysis considering dominant taxa. More comprehensive 334 characterisation of the clinical status of the patient group in this study (e.g. use of the 335 bronchiectasis severity index score [BSI]) would have useful, given the heterogeneity of the 336 BE patient population. However, this study pre-dated the publication of the BSI score and a 337 component of this composite measure (MRC dyspnoea score) was not collected. Collection 338 of validated composite measure data alongside microbiota data in future studies would 339 facilitate this analysis. This study used spontaneously expectorated sputum samples whereas 340 it could be argued that induced sputum may be more representative by providing greater 341 coverage of the airway. Previous studies including spontaneously expectorated sputum, 342 induced sputum and BAL have shown that although bacterial diversity reported across each 343 method differed in sensitivity, the content was not significantly different (28). Studies based on marker-gene sequencing of short amplicons have an inherent lack of taxonomic resolution to the level of species. Hence, limitations associated with using genus-level bacterial data, as described in this study, may mask any potential differences in how different bacterial species and/or strains within the same genera interact with their human host. $(21,31)$

In conclusion, we report a significant correlation between bacterial community composition in subjects with $\mathrm{BE}$, markers of chest HRCT and blood inflammatory markers. The association between loss of diversity and chest HRCT severity suggests bacterial dominance with pathogenic bacteria may contribute to disease pathology.

Acknowledgements:

This study was supported by a fellowship grant from the Health and Social Care Research and Development, Public Health Agency, Northern Ireland (S.R.). Permission to use custom software used to analyse LCl measurements was kindly given by Dr. Nicolas Bell. 
(1) Pasteur MC, Bilton D, Hill AT, British Thoracic Society Bronchiectasis non-CF Guideline Group. British Thoracic Society guideline for non-CF bronchiectasis. Thorax 2010 Jul;65 Suppl 1:i1-58.

(2) Polverino E, Goeminne PC, McDonnell MJ, Aliberti S, Marshall SE, Loebinger MR, et al. European Respiratory Society guidelines for the management of adult bronchiectasis. Eur Respir J 2017 Sep 9;50(3):10.1183/13993003.00629-2017. Print 2017 Sep.

(3) Faner R, Sibila O, Agusti A, Bernasconi E, Chalmers JD, Huffnagle GB, et al. The microbiome in respiratory medicine: current challenges and future perspectives. Eur Respir $\mathrm{J}$ 2017 Apr 12;49(4):10.1183/13993003.02086-2016. Print 2017 Apr.

(4) Chalmers JD, Aliberti S, Filonenko A, Shteinberg M, Goeminne PC, Hill AT, et al. Characterization of the "Frequent Exacerbator Phenotype" in Bronchiectasis. Am J Respir Crit Care Med 2018 Jun 1;197(11):1410-1420.

(5) Tunney MM, Einarsson GG, Wei L, Drain M, Klem ER, Cardwell C, et al. Lung microbiota and bacterial abundance in patients with bronchiectasis when clinically stable and during exacerbation. Am J Respir Crit Care Med 2013 May 15;187(10):1118-1126.

(6) Rowan SA, Bradley JM, Bradbury I, Lawson J, Lynch T, Gustafsson P, et al. Lung Clearance Index Is a Repeatable and Sensitive Indicator of Radiological Changes in Bronchiectasis. Am J Respir Crit Care Med 2014 03/01; 2014/03;189(5):586-592.

(7) Health Protection Agency. UK Standards for Microbiology Investigations. Investigation of

(8) Lee TWR, Brownlee KG, Conway SP, Denton M, Littlewood JM. Evaluation of a new definition for chronic Pseudomonas aeruginosa infection in cystic fibrosis patients. Journal of Cystic Fibrosis 2003 3;2(1):29-34.

(9) Brody AS, Klein JS, Molina PL, Quan J, Bean JA, Wilmott RW. High-resolution computed tomography in young patients with cystic fibrosis: distribution of abnormalities and correlation with pulmonary function tests. J Pediatr 2004 Jul;145(1):32-38.

(10) Miller MR, Hankinson J, Brusaco V, Burgos F, Casaburi R, Coates A, et al. Standadization of spirometry. Eur Resp J 2005;26.

394 (11) Stanojevic S, Wade A, Stocks J, Hankinson J, Coates AL, Pan H, et al. Reference 395 Ranges for Spirometry Across All Ages. American Journal of Respiratory and Critical Care 396 Medicine 2008 February 01;177(3):253-260.

397 (12) Horsley AR, Gustafsson PM, Macleod KA, Saunders C, Greening AP, Porteous DJ, et 398 al. Lung clearance index is a sensitive, repeatable and practical measure of airways disease 399 in adults with cystic fibrosis. Thorax 2008 Feb;63(2):135-140.

400 (13) O'Neill K, Tunney MM, Johnston E, Rowan S, Downey DG, Rendall J, et al. Lung 401 Clearance Index in Adults and Children With Cystic Fibrosis. Chest 2016 Dec;150(6):13234021332. 
403 (14) Oksanen J, Blanchet F, Kindt R, Legendre P, Minchin P, O'hara R, et al. Package 404 'vegan'. Community ecology package, version. 2013;2(9).

405 (15) Kassambara A. ggpubr:"ggplot2" based publication ready plots. R package version 0.1. $406 \quad 2017 ; 6$.

407 (16) Revelle W. Procedures for psychological, psychometric, and personality research. 408 Northwestern University, Evanston, Illinois. 2014;165.

409 (17) O'Neill K, Bradley JM, Johnston E, McGrath S, Mcllreavey L, Rowan S, et al. Reduced 410 bacterial colony count of anaerobic bacteria is associated with a worsening in lung clearance 411 index and inflammation in cystic fibrosis. PLoS One 2015 May 20;10(5):e0126980.

412 (18) Davies G, Wells AU, Doffman S, Watanabe S, Wilson R. The effect of Pseudomonas 413 aeruginosa on pulmonary function in patients with bronchiectasis. Eur Respir J 2006 414 European Respiratory Society;28(5):974-979.

415 (19) Evans SA, Turner SM, Bosch BJ, Hardy CC, Woodhead MA. Lung function in 416 bronchiectasis: the influence of Pseudomonas aeruginosa. Eur Respir J 1996 417 Aug;9(8):1601-1604.

418 (20) Owens CM, Aurora P, Stanojevic S, Bush A, Wade A, Oliver C, et al. Lung Clearance 419 Index and HRCT are complementary markers of lung abnormalities in young children with 420 CF. Thorax 2011 June 01;66(6):481-488.

(21) Einarsson GG, Comer DM, Mcllreavey L, Parkhill J, Ennis M, Tunney MM, et al. Community dynamics and the lower airway microbiota in stable chronic obstructive pulmonary disease, smokers and healthy non-smokers. Thorax 2016 BMJ Publishing Group

(22) Cox MJ, Allgaier M, Taylor B, Baek MS, Huang YJ, Daly RA, et al. Airway Microbiota and Pathogen Abundance in Age-Stratified Cystic Fibrosis Patients. PLoS ONE 2010 06/23;5(6):e11044.

(23) Coburn B, Wang PW, Diaz Caballero J, Clark ST, Brahma V, Donaldson S, et al. Lung microbiota across age and disease stage in cystic fibrosis. Sci Rep 2015 May 14;5:10241.

(24) Cox MJ, Turek EM, Hennessy C, Mirza GK, James PL, Coleman M, et al. Longitudinal assessment of sputum microbiome by sequencing of the 16S rRNA gene in non-cystic fibrosis bronchiectasis patients. PLoS One 2017 Feb 7;12(2):e0170622.

(25) Klepac-Ceraj V, Lemon KP, Martin TR, Allgaier M, Kembel SW, Knapp AA, et al.

434 Relationship between cystic fibrosis respiratory tract bacterial communities and age, 435 genotype, antibiotics and Pseudomonas aeruginosa. Environ Microbiol 2010 436 May;12(5):1293-1303.

437 (26) Zemanick ET, Wagner BD, Robertson CE, Ahrens RC, Chmiel JF, Clancy JP, et al. 438 Airway microbiota across age and disease spectrum in cystic fibrosis. Eur Respir J 2017 Nov 439 16;50(5):10.1183/13993003.00832-2017. Print 2017 Nov.

440 (27) Zhao J, Schloss PD, Kalikin LM, Carmody LA, Foster BK, Petrosino JF, et al. Decade441 long bacterial community dynamics in cystic fibrosis airways. Proceedings of the National 442 Academy of Sciences 2012 April 10;109(15):5809-5814. 
443 (28) Rogers GB, van der Gast CJ, Cuthbertson L, Thomson SK, Bruce KD, Martin ML, et al. 444 Clinical measures of disease in adult non-CF bronchiectasis correlate with airway microbiota 445 composition. Thorax 2013 Aug;68(8):731-737.

446 (29) Rogers GB, Zain NM, Bruce KD, Burr LD, Chen AC, Rivett DW, et al. A novel 447 microbiota stratification system predicts future exacerbations in bronchiectasis. Ann Am 448 Thorac Soc 2014 May; 11(4):496-503.

449 (30) Sherrard LJ, Einarsson GG, Johnston E, O'Neill K, Mcllreavey L, McGrath SJ, et al. 450 Assessment of stability and fluctuations of cultured lower airway bacterial communities in 451 people with cystic fibrosis. J Cyst Fibros 2019 Mar 21.

452 (31) Erb-Downward J, Thompson DL, Han MK, Freeman CM, McCloskey L, Schmidt LA, et 453 al. Analysis of the Lung Microbiome in the Healthy $\square$ Smoker and in COPD. PLoS ONE 2011 $454 \quad$ 02/22;6(2):e16384. 
Table 1: Characteristics of study subjects $(n=21)$

\begin{tabular}{|c|c|}
\hline & Subjects $(n=21)$ \\
\hline Mean (SD) age in years & $64.0(7.7)$ \\
\hline Females: males $(n)$ & $14: 7$ \\
\hline $\begin{array}{l}\text { Ethnicity } \\
\text { n (\%) Caucasian }\end{array}$ & $21(100)$ \\
\hline $\begin{array}{l}\text { Smoking status } \\
\text { n (\%) Non-smoker } \\
\text { n (\%) Ex-smoker }\end{array}$ & $\begin{array}{l}17(81) \\
4(19)\end{array}$ \\
\hline $\begin{array}{l}\text { Disease aetiology } \\
\text { n (\%) Post infectious } \\
\text { n (\%) No cause identified } \\
\text { n (\%) Inflammatory bowel disease } \\
\text { n (\%) Connective tissue disease } \\
\text { n (\%) Immune defect }\end{array}$ & $\begin{array}{l}9(43) \\
9(43) \\
1(5) \\
1(5) \\
1(5)\end{array}$ \\
\hline $\begin{array}{l}\text { Medication use } \\
\text { Oral antibiotics } \\
\text { Mucoactives } \\
\text { Inhaled antibiotics } \\
\text { Macrolides } \\
\text { Inhaled corticosteroids } \\
\text { Inhaled bronchodilators }\end{array}$ & $\begin{array}{l}2(9.5) \\
2(9.5) \\
3(14.3) \\
9(42.9) \\
18(85.7) \\
19(90.5)\end{array}$ \\
\hline $\begin{array}{l}\text { Routine lab culture } \\
\mathrm{n}(\%) H \text {. influenzae } \\
\mathrm{n}(\%) \text { no significant growth } \\
\mathrm{n}(\%) P . \text { aeruginosa } \\
\mathrm{n}(\%) \text { S. pneumoniae }\end{array}$ & $\begin{array}{l}9(43) \\
8(38) \\
3(14) \\
1(5)\end{array}$ \\
\hline n (\%) chronic $P$. aeruginosa infection* (8) & $2(10)$ \\
\hline Number of PEx in last year & $0.2(0.5)[0-2]$ \\
\hline $\begin{array}{l}\text { Mean (range) bacterial community richness (no. } \\
\text { species) }\end{array}$ & $27(9-45)$ \\
\hline Mean (range) bacterial community evenness & $0.19(0.07-0.29)$ \\
\hline Mean (range) bacterial community dominance & $0.41(0.17-0.94)$ \\
\hline Mean (range) Shannon Wiener Index & $1.47(0.17-2.41)$ \\
\hline Mean (SD) $\mathrm{FEV}_{1} \%$ predicted & $76.5(17.2)[40-110]$ \\
\hline Mean (SD) $\mathrm{FEF}_{25-75} \%$ predicted & $61.4(30.8)[22-168]$ \\
\hline
\end{tabular}




\begin{tabular}{|l|l|}
\hline Mean (SD) LCl no. turnovers [range] & $9.5(1.7)[7.3$ to 12.9] \\
\hline Mean (SD) CRP mg/L & $4.1(4.2)[1-20]$ \\
\hline Mean (SD) WCC x 10\%/L & $7.0(1.8)[4-10.8]$ \\
\hline
\end{tabular}

PEx: pulmonary exacerbation

WCC: white cell count

CRP: C-reactive protein

${ }^{*}$ Routine culture 
Table 2: Univariate correlations (Spearman's rank correlation coefficient) for clinical variables and the main ecological indices of the bacterial community composition $(n=$ 21). P-value $<0.05$ denote significance.

\begin{tabular}{|c|c|c|c|c|}
\hline & $\begin{array}{l}\text { Richness } \\
{[\mathrm{S}]}\end{array}$ & $\begin{array}{c}\text { Shannon } \\
{[\mathrm{H}]}\end{array}$ & $\begin{array}{c}\text { Evenness } \\
{\left[\mathbf{e}^{\mathrm{H} / \mathrm{s}}\right]}\end{array}$ & $\begin{array}{c}\text { Dominance } \\
\text { [D] }\end{array}$ \\
\hline HRCT Total & $\begin{array}{l}-0.456 \\
(0.038)\end{array}$ & $\begin{array}{l}-0.544 \\
(0.011)\end{array}$ & $\begin{array}{l}-0.429 \\
(0.052)\end{array}$ & $\begin{array}{c}0.546 \\
(0.010)\end{array}$ \\
\hline Bronchiectasis & $\begin{array}{l}-0.567 \\
(0.007)\end{array}$ & $\begin{array}{l}-0.655 \\
(0.001)\end{array}$ & $\begin{array}{l}-0.474 \\
(0.030)\end{array}$ & $\begin{array}{c}0.654 \\
(0.001)\end{array}$ \\
\hline Airway Thickening & $\begin{array}{l}-0.306 \\
(0.178)\end{array}$ & $\begin{array}{l}-0.415 \\
(0.061)\end{array}$ & $\begin{array}{l}-0.443 \\
(0.044)\end{array}$ & $\begin{array}{c}0.389 \\
(0.082)\end{array}$ \\
\hline Mucus Plugging & $\begin{array}{l}-0.273 \\
(0.232)\end{array}$ & $\begin{array}{l}-0.347 \\
(0.123)\end{array}$ & $\begin{array}{l}-0.192 \\
(0.405)\end{array}$ & $\begin{array}{c}0.309 \\
(0.172)\end{array}$ \\
\hline Parenchymal & $\begin{array}{l}-0.453 \\
(0.039)\end{array}$ & $\begin{array}{l}-0.489 \\
(0.024)\end{array}$ & $\begin{array}{l}-0.323 \\
(0.153)\end{array}$ & $\begin{array}{c}0.453 \\
(0.039)\end{array}$ \\
\hline Air Trapping & $\begin{array}{l}-0.242 \\
(0.291)\end{array}$ & $\begin{array}{l}-0.286 \\
(0.209)\end{array}$ & $\begin{array}{l}-0.219 \\
(0.340)\end{array}$ & $\begin{array}{c}0.289 \\
(0.204)\end{array}$ \\
\hline CRP mg/L & $\begin{array}{l}-0.394 \\
(0.077)\end{array}$ & $\begin{array}{l}-0.467 \\
(0.033)\end{array}$ & $\begin{array}{l}-0.338 \\
(0.134)\end{array}$ & $\begin{array}{c}0.494 \\
(0.023)\end{array}$ \\
\hline WCC $\times 10^{9} / \mathrm{L}$ & $\begin{array}{l}-0.442 \\
(0.045)\end{array}$ & $\begin{array}{l}-0.422 \\
(0.056)\end{array}$ & $\begin{array}{l}-0.121 \\
(0.601)\end{array}$ & $\begin{array}{c}0.408 \\
(0.067)\end{array}$ \\
\hline $\mathrm{FEV}_{1} \%$ predicted & $\begin{array}{l}-0.106 \\
(0.646)\end{array}$ & $\begin{array}{c}-0.01 \\
(0.964)\end{array}$ & $\begin{array}{l}-0.01 \\
(0.966)\end{array}$ & $\begin{array}{c}0.048 \\
(0.836)\end{array}$ \\
\hline FEF $_{25-75} \%$ predicted & $\begin{array}{l}-0.144 \\
(0.533)\end{array}$ & $\begin{array}{l}-0.023 \\
(0.920)\end{array}$ & $\begin{array}{c}0.007 \\
(0.975)\end{array}$ & $\begin{array}{c}0.012 \\
(0.958)\end{array}$ \\
\hline $\begin{array}{l}\mathrm{LCl} \text { (no. of } \\
\text { turnovers) }\end{array}$ & $\begin{array}{l}-0.194 \\
(0.400)\end{array}$ & $\begin{array}{l}-0.214 \\
(0.351)\end{array}$ & $\begin{array}{l}-0.087 \\
(0.707)\end{array}$ & $\begin{array}{c}0.161 \\
(0.485)\end{array}$ \\
\hline
\end{tabular}




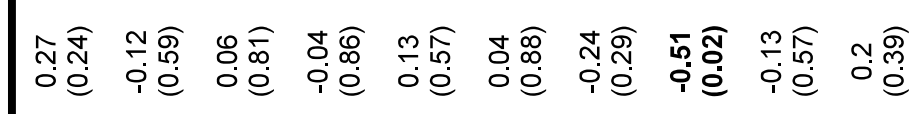

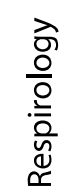

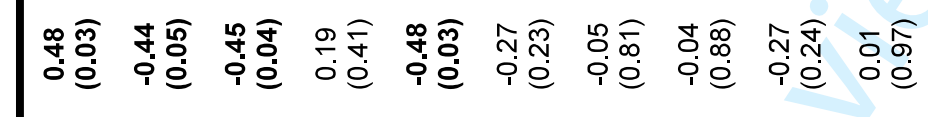

môn

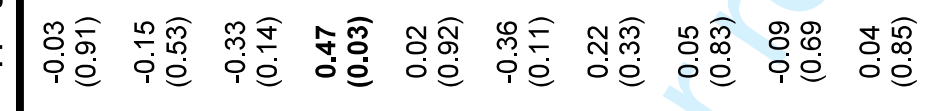

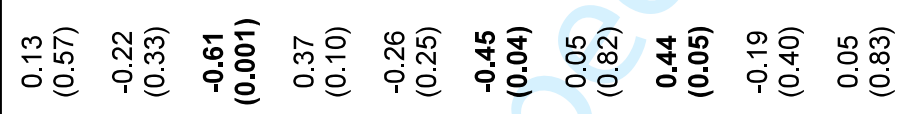

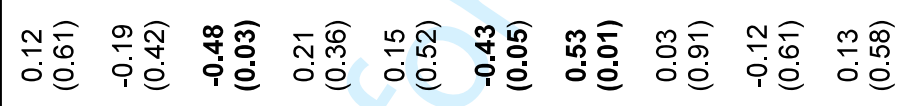

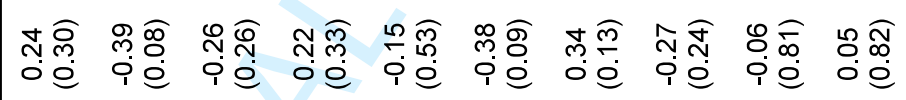

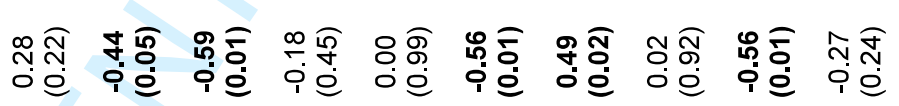

के

車

a

농 을

은 


\section{Supplementary Figure legends}

A Scatterplot and univariate linear regression analysis between air trapping HRCT score (vertical axis; dependent variable) and ecological measurements for bacterial community composition (horizontal axis).

B Scatterplot and univariate linear regression analysis between airway thickening HRCT score (vertical axis; dependent variable) and ecological measurements for bacterial community composition (horizontal axis).

C Scatterplot and univariate linear regression analysis between bronchiectasis HRCT score (vertical axis; dependent variable) and ecological measurements for bacterial community composition (horizontal axis).

D Scatterplot and univariate linear regression analysis between mucus plugging HRCT score (vertical axis; dependent variable) and ecological measurements for bacterial community composition (horizontal axis).

E Scatterplot and univariate linear regression analysis between parenchymal HRCT score (vertical axis; dependent variable) and ecological measurements for bacterial community composition (horizontal axis).

F Scatterplot and univariate linear regression analysis between total HRCT score (vertical axis; dependent variable) and ecological measurements for bacterial community composition (horizontal axis).

G Scatterplot and univariate linear regression analysis between blood CRP (vertical axis; dependent variable) and ecological measurements for bacterial community composition (horizontal axis).

H Scatterplot and univariate linear regression analysis between blood WCC (vertical axis; dependent variable) and ecological measurements for bacterial community composition (horizontal axis).

I Scatterplot and univariate linear regression analysis between $\mathrm{FEV}_{1} \%$ predicted (vertical axis; dependent variable) and ecological measurements for bacterial community composition (horizontal axis).

J Scatterplot and univariate linear regression analysis between $\mathrm{FEF}_{25-75} \%$ predicted (vertical axis; dependent variable) and ecological measurements for bacterial community composition (horizontal axis).

K Scatterplot and univariate linear regression analysis between LCl (vertical axis; dependent variable) and ecological measurements for bacterial community composition (horizontal axis). 


\section{Supplementary information}

Title: The composition of the airway bacterial community correlates with chest HRCT in adults with bronchiectasis

Katherine O'Neill $\mathrm{PhD}^{1}$, *

Gisli G Einarsson $\mathrm{PhD}^{1}$,

Stephen Rowan²,

Leanne Mcllreavey ${ }^{3}$,

Andrew J. Lee $\mathrm{PhD}^{1}$,

John Lawson ${ }^{4}$,

Tom Lynch ${ }^{4}$

Alex Horsley ${ }^{5}$,

Judy. M. Bradley $\mathrm{PhD}^{1}$,

J. Stuart Elborn ${ }^{1, * *}$

Michael M Tunney ${ }^{3}, *$

${ }^{1}$ Wellcome-Wolfson Institute For Experimental Medicine, School of Medicine, Dentistry and Biomedical Sciences, Queen's University Belfast, United Kingdom

${ }^{2}$ South Eastern Health and Social Care Trust, United Kingdom

${ }^{3}$ School of Pharmacy, Queen's University Belfast, United Kingdom

${ }^{4}$ Belfast Health and Social Care Trust, United Kingdom

${ }^{5}$ Manchester Adult Cystic Fibrosis Centre, University Hospitals of South Manchester, Manchester, United Kingdom

*Joint first authors

** Joint senior authors

Corresponding author: Dr Katherine O'Neill, Wellcome-Wolfson Institute For Experimental Medicine, School of Medicine, Dentistry and Biomedical Sciences, Queen's University Belfast. k.oneill@qub.ac.uk 


\section{Supplementary appendix 1: Inclusion and exclusion criteria}

Supplementary appendix 2 and Supplementary Table 1: Complete HRCT protocol and scoring system

Supplementary appendix 3: Statistical analysis

Supplementary Figure 1 A-K

Supplementary Table 2: Relative abundance defined as the proportion of taxa in each of the samples

\section{Supplementary appendix 1: Inclusion and exclusion criteria}

Patients were included if (1) they were 18-80 years of age; (2) a diagnosis of BE was confirmed, based on a CT report in the clinical notes, which described any evidence of BE. BE only was included. If only bronchial wall thickening was present, the patient was excluded. Traction BE was not included; (3) patients in the study were non-smokers or ex-smokers with a less than 10-pack year smoking history; and (4) were free of exacerbation symptoms (as defined by British Thoracic Society guidelines) for at least 4 weeks before taking part in the study (1). Patients were excluded if significant comorbidity was present (e.g., congestive cardiac failure, neoplasm).

\section{Supplementary appendix 2: Complete HRCT protocol and scoring system}

The exposure protocol for the inspiratory scan uses a kilovoltage of $120 \mathrm{kVp}$ with the apex to the base of the lung scanned using a collimation of $1.25 \mathrm{~mm}$ with a slice interval of $10 \mathrm{~mm}$. Expiratory scans were performed at approximately 6 levels. The typical CT dose length product for this scan protocol is $30 \mathrm{mGy} . \mathrm{cm}$. The radiation dose to the patient for these scans was calculated using the Impact CT dose calculator using information on the scan protocol and radiation output data from the CT scanner. 
The level of exposure is associated with a 1:10000 additional risk of a lifetime cancer for the participants. In context, the level of exposure is approximately equivalent to 18 months exposure to natural background radiation.

The risks of radiation exposure are minimal through selection of a protocol that exposes only $10 \%$ of the total volume of the lung. Pregnancy, breast feeding and children $<18$ years old were excluded.

The majority of patients in this study have reached full maturation of tissues and thereby decrease the risk of tissue damage and cancers compared with younger developing tissues.

The scoring system used is summarised in the supplementary table below (supplementary table 1) and elaborated in the original article (2).

Table 1. The scoring system from Brody et al used to grade the severity of radiological abnormalities seen in patients with $\mathrm{BE}$.

\begin{tabular}{|c|c|c|c|}
\hline \multicolumn{4}{|c|}{ HRCT Scoring System } \\
\hline $\begin{array}{l}\text { Bronchiectasis } \\
\text { Score (range, } \\
0-12 \text { ) }\end{array}$ & $\begin{array}{l}\text { = Extent of } \\
\text { bronchiectasis in } \\
\text { central lung } \\
0=\text { none } \\
1=1 / 3 \text { of lobe } \\
2=1 / 3-2 / 3 \text { of lobe } \\
3 \geq 2 / 3 \text { of lobe }\end{array}$ & $\begin{array}{l}+ \text { Extent of } \\
\text { bronchiectasis in } \\
\text { peripheral lung } \\
0=\text { none } \\
1=1 / 3 \text { of lobe } \\
2=1 / 3-2 / 3 \text { of lobe } \\
3 \geq 2 / 3 \text { of lobe }\end{array}$ & $\begin{array}{l}\mathbf{X} \text { Average } \\
\text { bronchiectasis size } \\
\text { multiplier } \\
\text { Average multiplier size } \\
0.5=0 \\
1=1 \\
1.5=1.25 \\
2.0=1.5 \\
2.5=1.75 \\
3=2\end{array}$ \\
\hline $\begin{array}{l}\text { Where average } \\
\text { bronchiectasis } \\
\text { size }\end{array}$ & $\begin{array}{l}=\text { Size of largest } \\
\text { dilated bronchus } \\
1 \leq 2 x \\
2=2 x-3 x \\
3 \geq 3 x\end{array}$ & $\begin{array}{l}+ \text { Average size of } \\
\text { dilated bronchi } \\
1 \leq 2 x \\
2=2 x-3 x \\
3 \geq 3 x\end{array}$ & $\div 2$ \\
\hline $\begin{array}{l}\text { Mucous } \\
\text { plugging score } \\
\text { (range 0-6) }\end{array}$ & $\begin{array}{l}=\text { Extent of } \\
\text { mucous plugging } \\
\text { in central lung } \\
0=\text { none } \\
1=1 / 3 \text { of lobe } \\
2=1 / 3-2 / 3 \text { of lobe } \\
3 \geq 2 / 3 \text { of lobe }\end{array}$ & $\begin{array}{l}+ \text { Extent of mucous } \\
\text { plugging in } \\
\text { peripheral lung } \\
0=\text { none } \\
1=1 / 3 \text { of lobe } \\
2=1 / 3-2 / 3 \text { of lobe } \\
3 \geq 2 / 3 \text { of lobe }\end{array}$ & \\
\hline $\begin{array}{l}\text { Peribronchial } \\
\text { thickening }\end{array}$ & $\begin{array}{l}=\text { Extent of } \\
\text { peribronchial }\end{array}$ & $\begin{array}{l}+ \text { Extent of } \\
\text { peribronchial }\end{array}$ & $\begin{array}{l}\text { X Severity of } \\
\text { peribronchial } \\
\text { thickening }\end{array}$ \\
\hline
\end{tabular}




\begin{tabular}{|c|c|c|c|}
\hline $\begin{array}{l}\text { score (range 0- } \\
\text { 9) }\end{array}$ & $\begin{array}{l}\text { thickening in } \\
\text { central lung } \\
0=\text { none } \\
1=1 / 3 \text { of lobe } \\
2=1 / 3-2 / 3 \text { of lobe } \\
3 \geq 2 / 3 \text { of lobe }\end{array}$ & $\begin{array}{l}\text { thickening in } \\
\text { peripheral lung } \\
0=\text { none } \\
1=1 / 3 \text { of lobe } \\
2=1 / 3-2 / 3 \text { of lobe } \\
3 \geq 2 / 3 \text { of lobe }\end{array}$ & $\begin{array}{l}1=\text { mild } \\
1.25=\text { moderate } \\
1.5=\text { severe }\end{array}$ \\
\hline $\begin{array}{l}\text { Parenchyma } \\
\text { score (range 0- } \\
\text { 9) }\end{array}$ & $\begin{array}{l}=\text { Extent of dense } \\
\text { parenchymal } \\
\text { opacity } \\
0=\text { none } \\
1=1 / 3 \text { of lobe } \\
2=1 / 3-2 / 3 \text { of lobe } \\
3 \geq 2 / 3 \text { of lobe } \\
\\
=\text { Extent of air } \\
\text { trapping } \\
0=\text { none } \\
1=1 / 3 \text { of lobe } \\
2=1 / 3-2 / 3 \text { of lobe } \\
3 \geq 2 / 3 \text { of lobe }\end{array}$ & $\begin{array}{l}+ \text { Extent of ground } \\
\text { glass opacity } \\
0=\text { none } \\
1=1 / 3 \text { of lobe } \\
2=1 / 3-2 / 3 \text { of lobe } \\
3 \geq 2 / 3 \text { of lobe } \\
\\
X \text { Appearance of air } \\
\text { trapping } \\
1=\text { sub segmental } \\
1.5=\text { segmental or } \\
\text { larger }\end{array}$ & $\begin{array}{l}+ \text { Extent of cysts or } \\
\text { bullae } \\
0=\text { none } \\
1=1 / 3 \text { of lobe } \\
2=1 / 3-2 / 3 \text { of lobe } \\
3 \geq 2 / 3 \text { of lobe }\end{array}$ \\
\hline
\end{tabular}

\section{Supplementary appendix 3: Statistical analysis}

Statistical analysis was performed in SPSS (version 21 PASW Statistics 21; IBM, Armonk, NY) and Prism (version 5.01; GraphPad Software Inc., La Jolla, CA) and in the R statistical environment (http://www.R-project.org) using the vegan package (version 2.4-6) (3). Ecological indices for the bacterial community composition (alpha diversity), i.e. taxonomic richness $[S]$, Shannon-Wiener diversity index $[H]$, evenness $\left[e^{H / S}\right]$ and dominance $[D]$ were calculated for each sample. The pair-wise relationship between clinical variables and ecological community indices were assessed using the Pearsons correlation coefficient using the psych package in $R$ (version 1.8.10) (4). Scatter- and linear regression plots were generated using the ggpubr package (version 0.1.8) (5).

Supplementary Figure 1 A-K: Scatterplot and univariate linear regression analysis clinical variables (vertical axis; dependent variable) and ecological measurements for bacterial community composition (horizontal axis). Spearman's correlation coefficient $(R)$ indicates the 
strength of the association between the relevant variables and $p<0.05$ denotes statistical significance. The shaded area around the scatter-points denotes the $95 \% \mathrm{Cl}$.

\section{Supplementary Table 2: Relative abundance defined as the proportion of taxa in each of the samples}

\section{References:}

(1) Pasteur MC, Bilton D, Hill AT, British Thoracic Society Bronchiectasis non-CF Guideline Group. British Thoracic Society guideline for non-CF bronchiectasis. Thorax $2010 \mathrm{Jul} ; 65$ Suppl 1:i1-58.

(2) Brody AS, Klein JS, Molina PL, Quan J, Bean JA, Wilmott RW. High-resolution computed tomography in young patients with cystic fibrosis: distribution of abnormalities and correlation with pulmonary function tests. J Pediatr 2004 Jul;145(1):32-38.

(3) Oksanen J, Blanchet F, Kindt R, Legendre P, Minchin P, O'hara R, et al. Package 'vegan'. Community ecology package, version. 2013;2(9).

(4) Revelle W. Procedures for psychological, psychometric, and personality research. Northwestern University, Evanston, Illinois. 2014;165.

(5) Kassambara A. ggpubr:"ggplot2" based publication ready plots. R package version 0.1. 2017;6. 

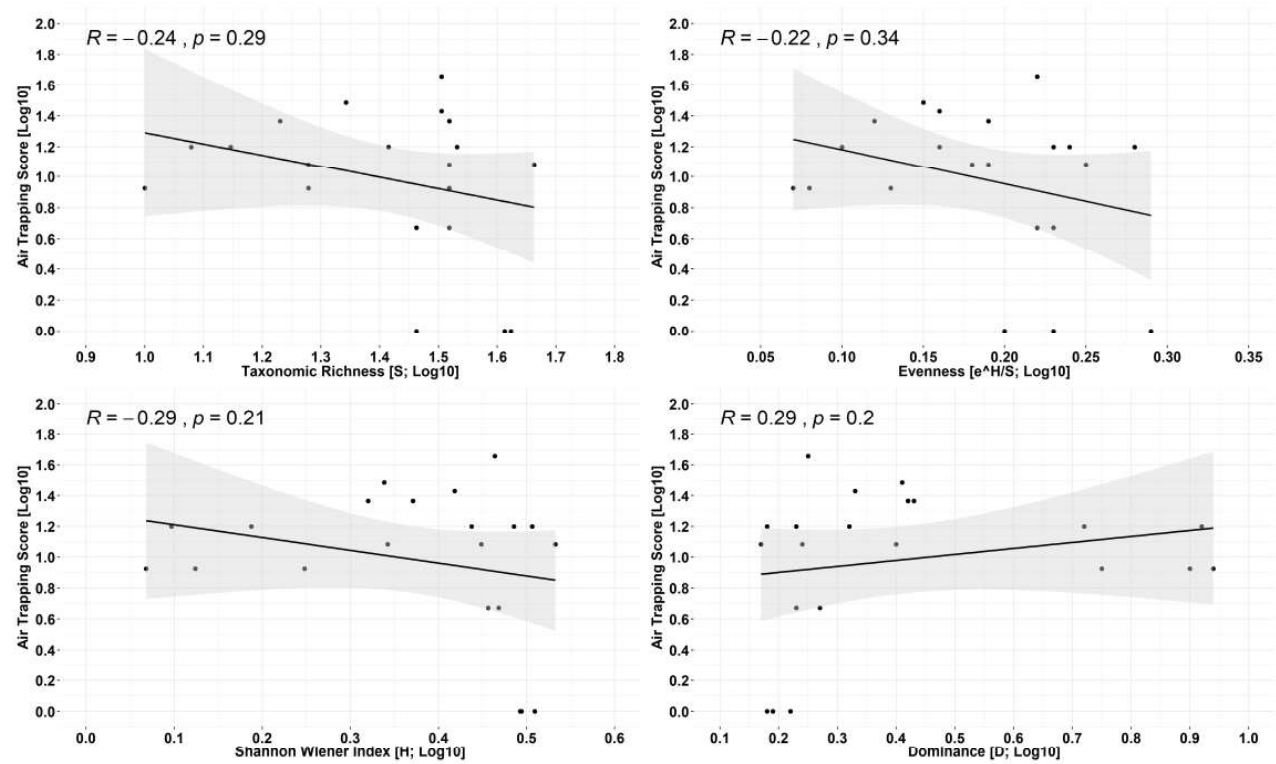

Supplementary Figure $1 \mathrm{~A}-\mathrm{K}$ : Scatterplot and univariate linear regression analysis clinical variables (vertical axis; dependent variable) and ecological measurements for microbial community composition (horizontal axis). Spearman's correlation coefficient $(R)$ indicates the strength of the association between the relevant variables and $p<0.05$ denotes statistical significance. The shaded area around the scatter-points denotes the $95 \% \mathrm{CI}$. 

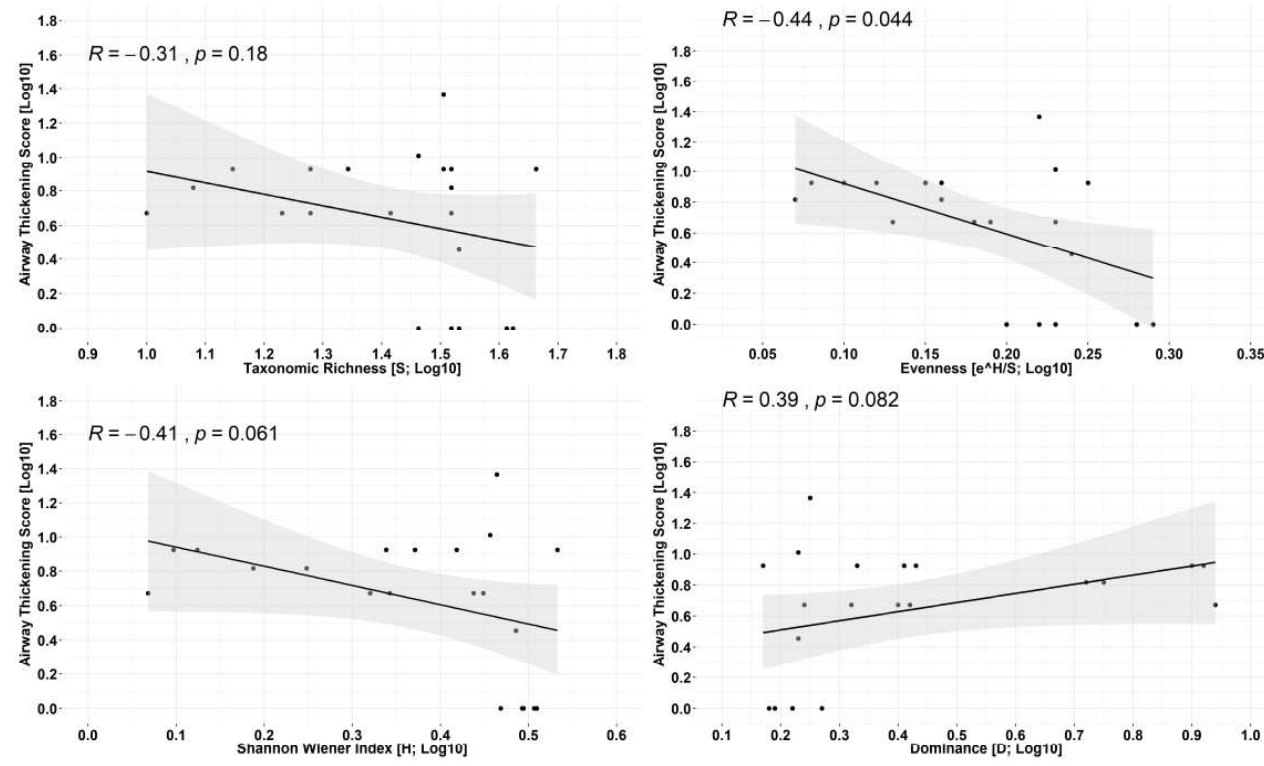

Supplementary Figure $1 \mathrm{~A}-\mathrm{K}$ : Scatterplot and univariate linear regression analysis clinical variables (vertical axis; dependent variable) and ecological measurements for microbial community composition (horizontal axis). Spearman's correlation coefficient $(R)$ indicates the strength of the association between the relevant variables and $p<0.05$ denotes statistical significance. The shaded area around the scatter-points denotes the $95 \%$ CI. 

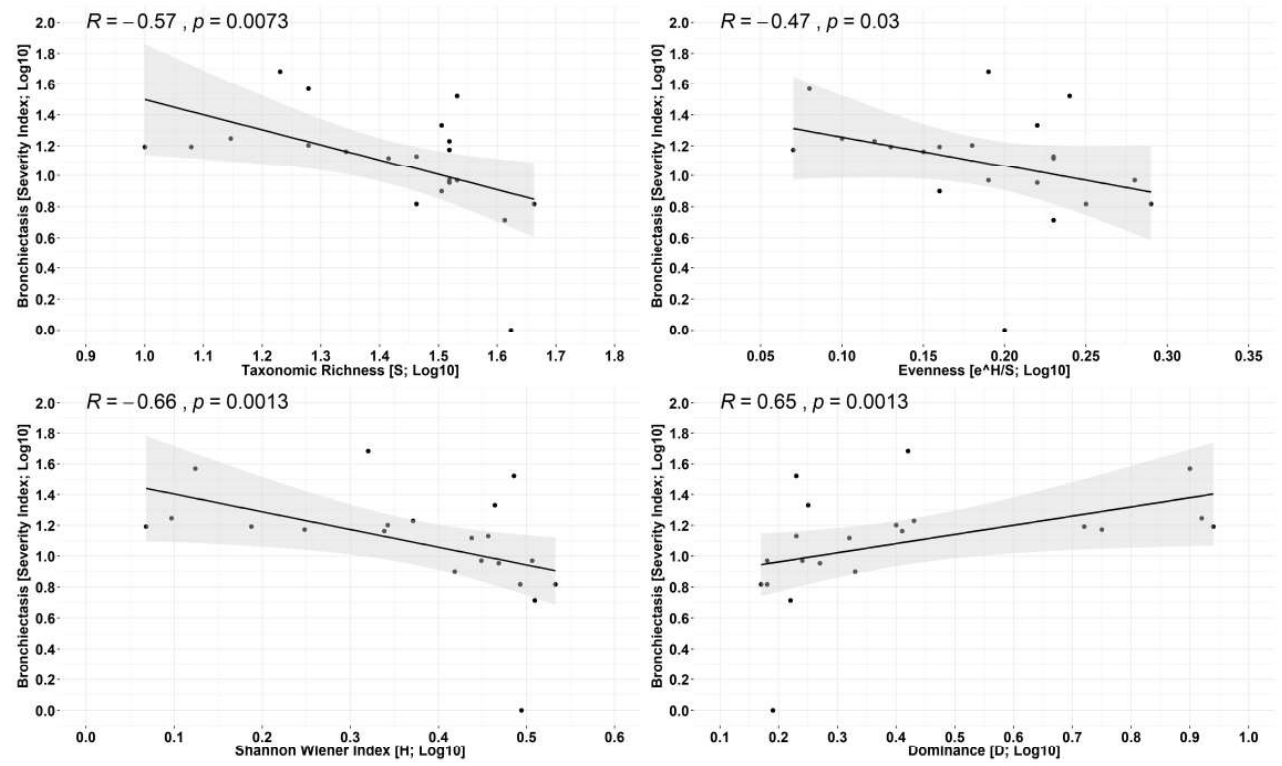

Supplementary Figure 1 A-K : Scatterplot and univariate linear regression analysis clinical variables (vertical axis; dependent variable) and ecological measurements for microbial community composition (horizontal axis). Spearman's correlation coefficient $(R)$ indicates the strength of the association between the relevant variables and $p<0.05$ denotes statistical significance. The shaded area around the scatter-points denotes the $95 \% \mathrm{CI}$. 

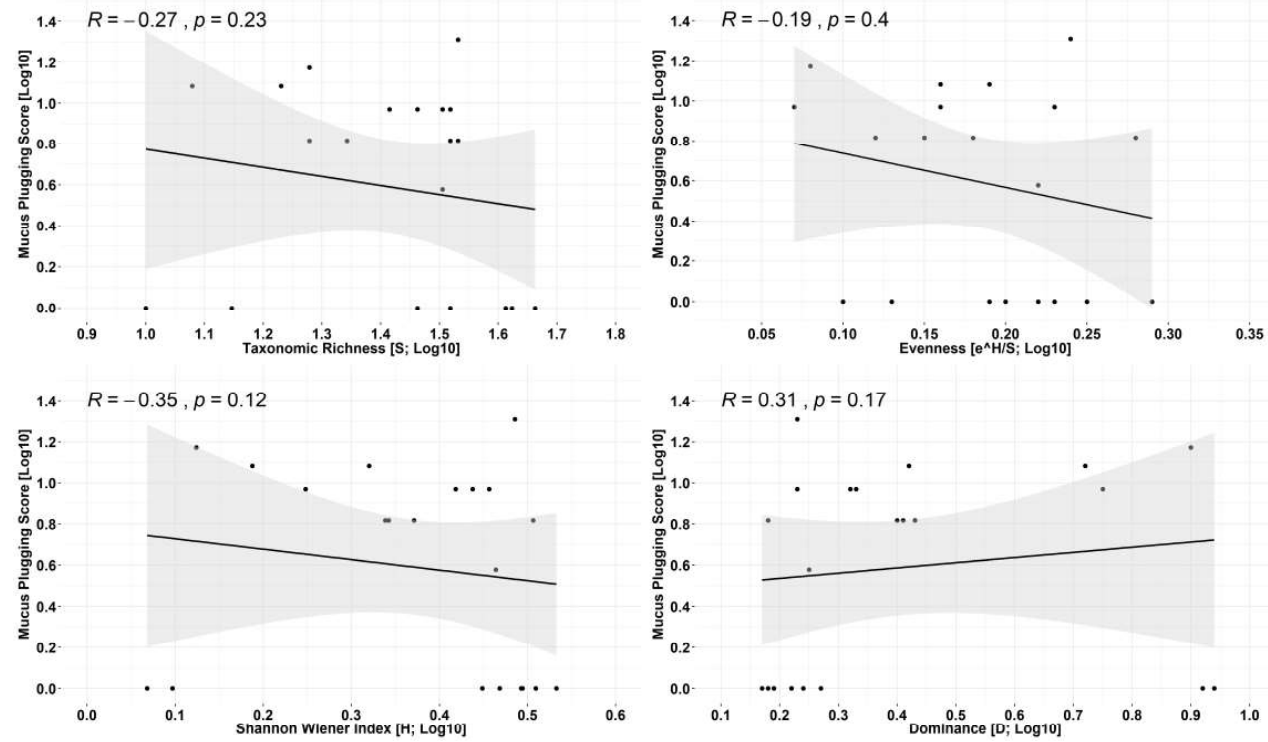

Supplementary Figure $1 \mathrm{~A}-\mathrm{K}$ : Scatterplot and univariate linear regression analysis clinical variables (vertical axis; dependent variable) and ecological measurements for microbial community composition (horizontal axis). Spearman's correlation coefficient $(R)$ indicates the strength of the association between the relevant variables and $p<0.05$ denotes statistical significance. The shaded area around the scatter-points denotes the $95 \%$ CI. 

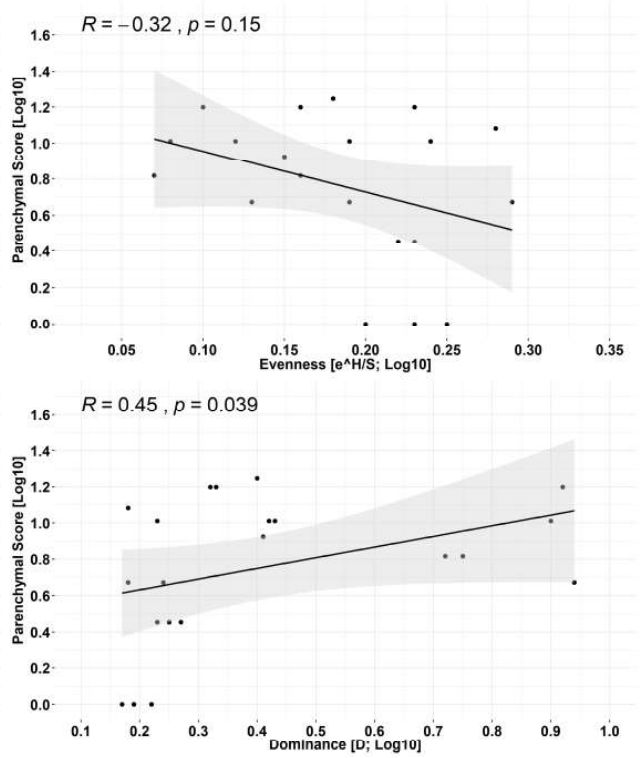

Supplementary Figure $1 \mathrm{~A}-\mathrm{K}$ : Scatterplot and univariate linear regression analysis clinical variables (vertical axis; dependent variable) and ecological measurements for microbial community composition (horizontal axis). Spearman's correlation coefficient ( $R$ ) indicates the strength of the association between the relevant variables and $p<0.05$ denotes statistical significance. The shaded area around the scatter-points denotes the $95 \%$ CI. 

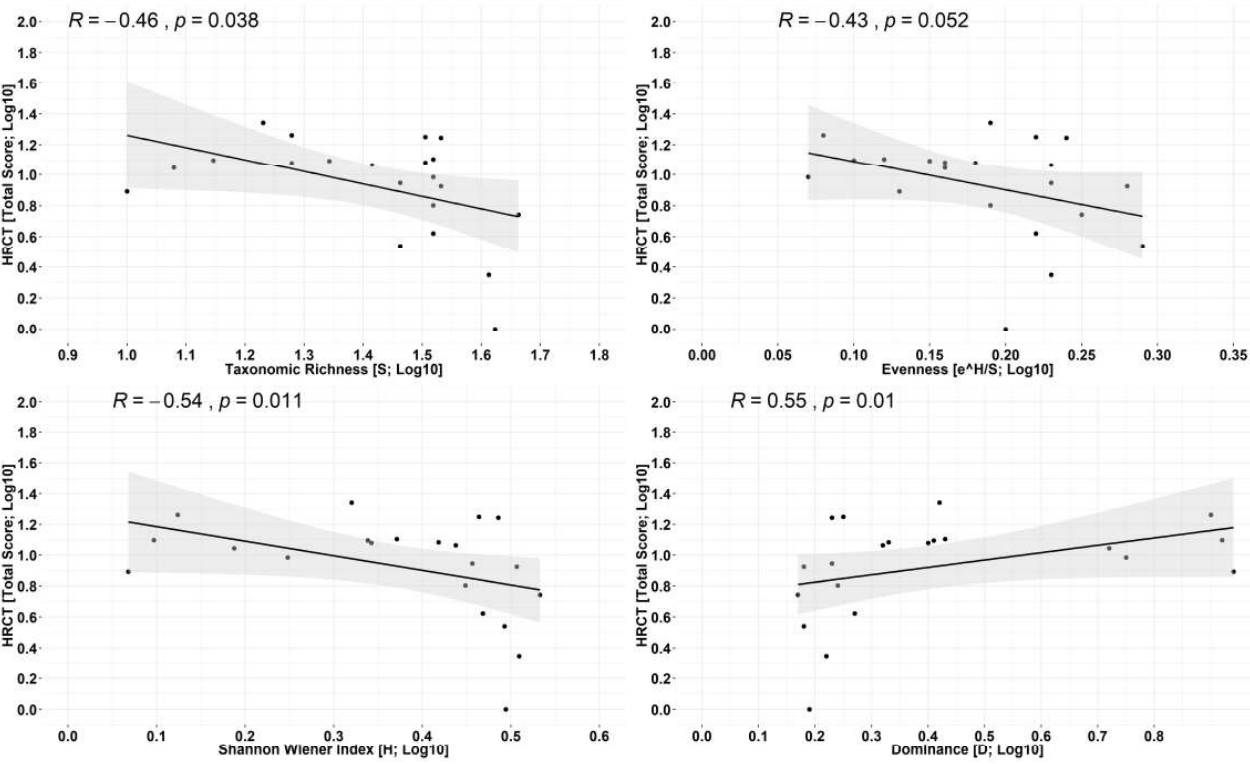

Supplementary Figure $1 \mathrm{~A}-\mathrm{K}$ : Scatterplot and univariate linear regression analysis clinical variables (vertical axis; dependent variable) and ecological measurements for microbial community composition (horizontal axis). Spearman's correlation coefficient $(R)$ indicates the strength of the association between the relevant variables and $p<0.05$ denotes statistical significance. The shaded area around the scatter-points denotes the $95 \%$ CI. 

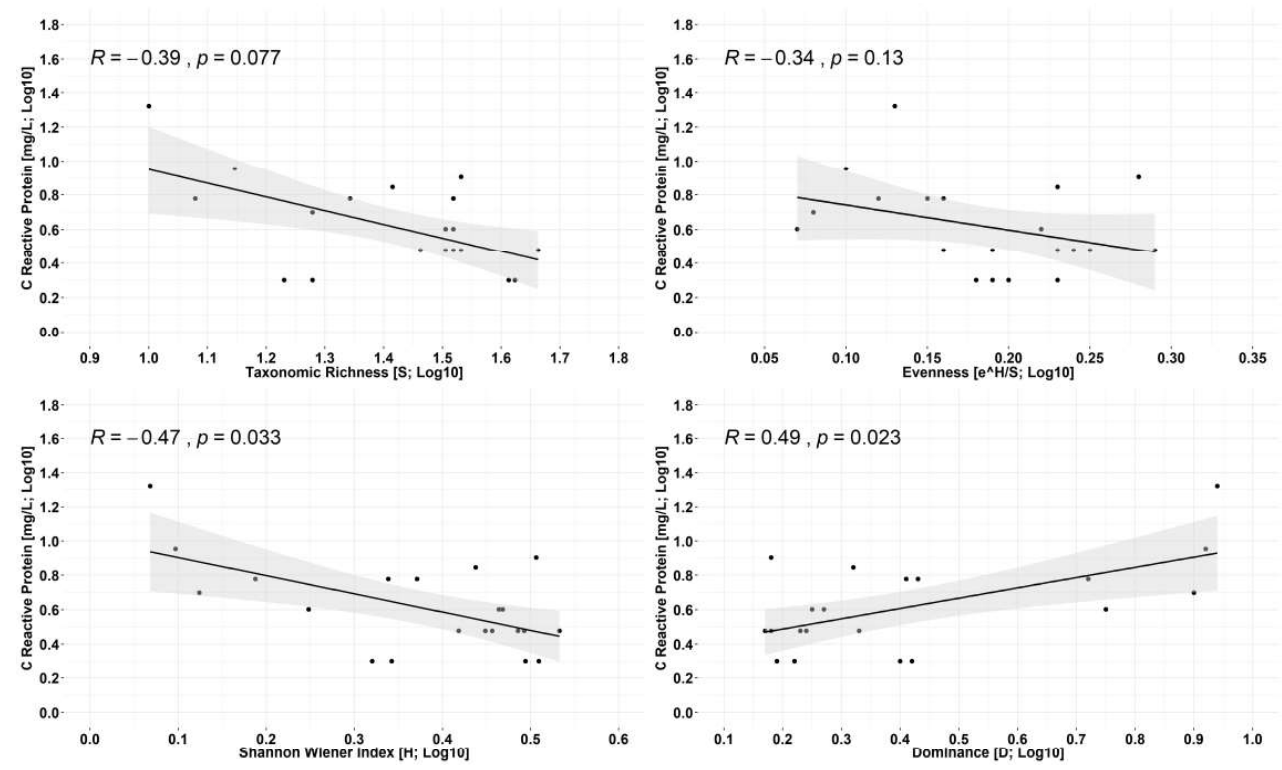

Supplementary Figure $1 \mathrm{~A}-\mathrm{K}$ : Scatterplot and univariate linear regression analysis clinical variables (vertical axis; dependent variable) and ecological measurements for microbial community composition (horizontal axis). Spearman's correlation coefficient $(R)$ indicates the strength of the association between the relevant variables and $p<0.05$ denotes statistical significance. The shaded area around the scatter-points denotes the $95 \%$ CI. 

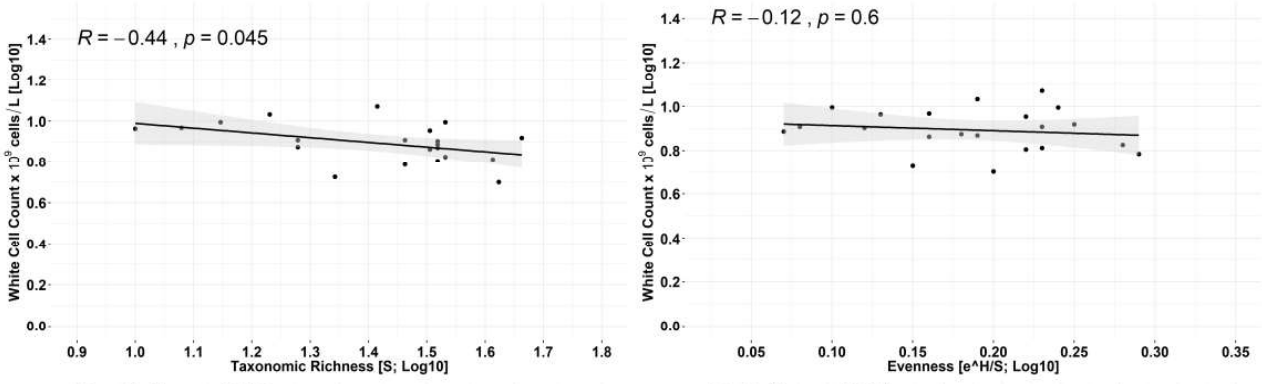

1.4. $R=-0.42, p=0.056$

1.4. $R=0.41, p=0.067$
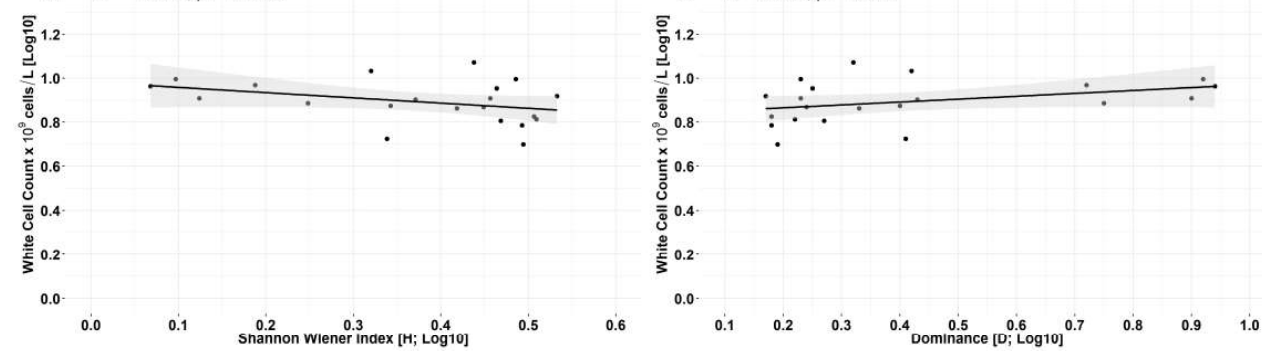

Supplementary Figure $1 \mathrm{~A}-\mathrm{K}$ : Scatterplot and univariate linear regression analysis clinical variables (vertical axis; dependent variable) and ecological measurements for microbial community composition (horizontal axis). Spearman's correlation coefficient $(R)$ indicates the strength of the association between the relevant variables and $p<0.05$ denotes statistical significance. The shaded area around the scatter-points denotes the $95 \% \mathrm{CI}$. 

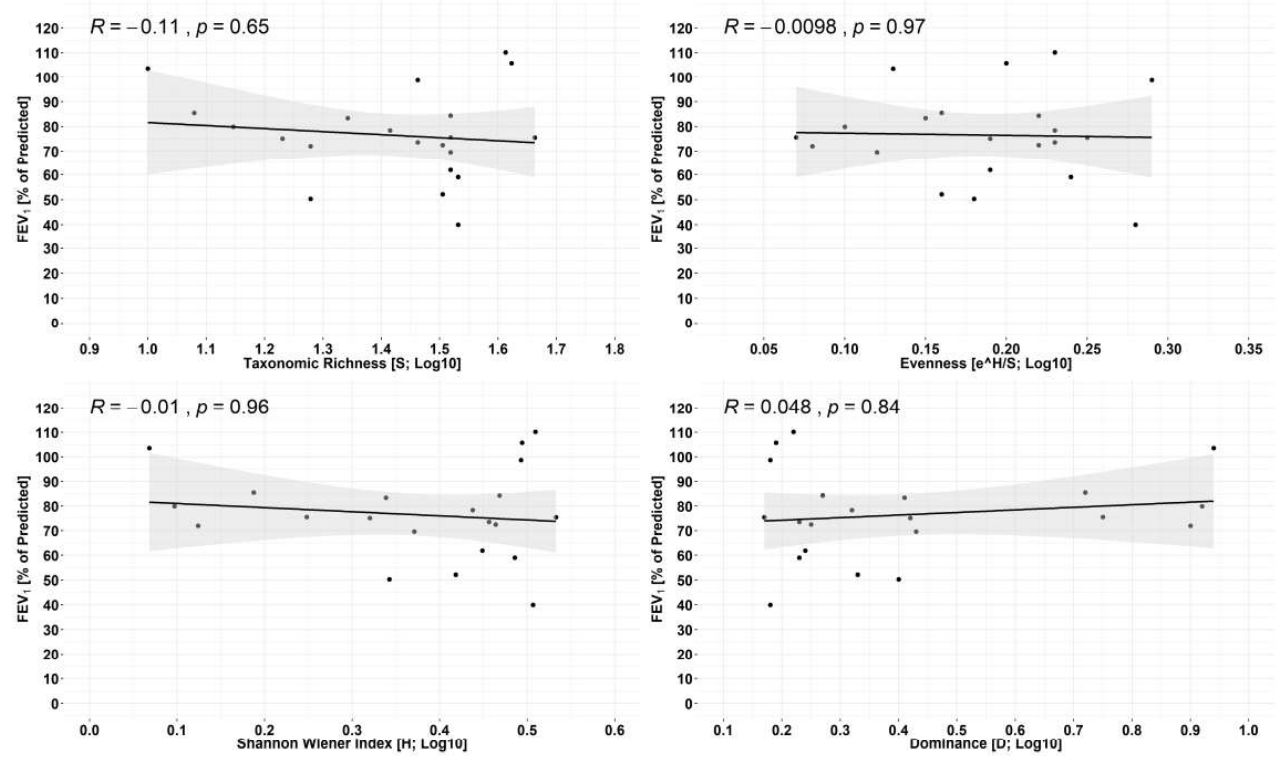

Supplementary Figure $1 \mathrm{~A}-\mathrm{K}$ : Scatterplot and univariate linear regression analysis clinical variables (vertical axis; dependent variable) and ecological measurements for microbial community composition (horizontal axis). Spearman's correlation coefficient $(R)$ indicates the strength of the association between the relevant variables and $p<0.05$ denotes statistical significance. The shaded area around the scatter-points denotes the $95 \% \mathrm{CI}$. 

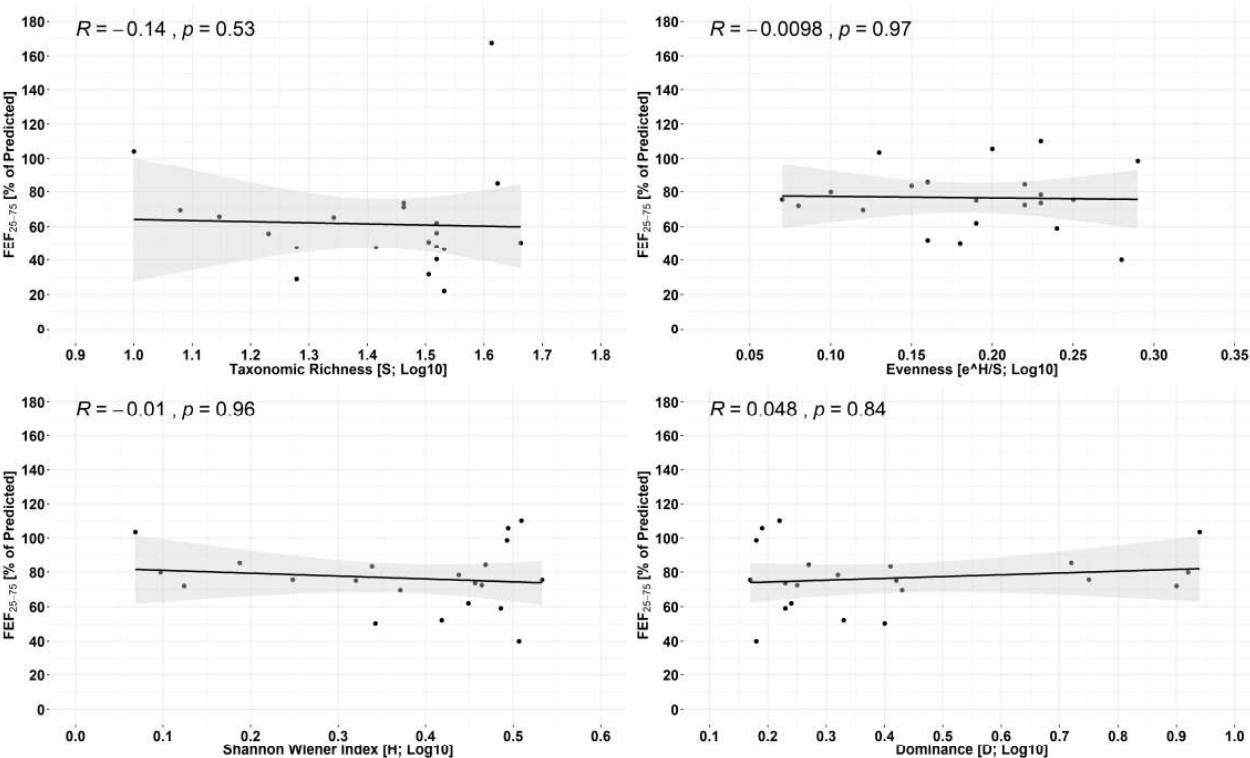

Supplementary Figure $1 \mathrm{~A}-\mathrm{K}$ : Scatterplot and univariate linear regression analysis clinical variables (vertical axis; dependent variable) and ecological measurements for microbial community composition (horizontal axis). Spearman's correlation coefficient $(R)$ indicates the strength of the association between the relevant variables and $p<0.05$ denotes statistical significance. The shaded area around the scatter-points denotes the $95 \% \mathrm{CI}$. 

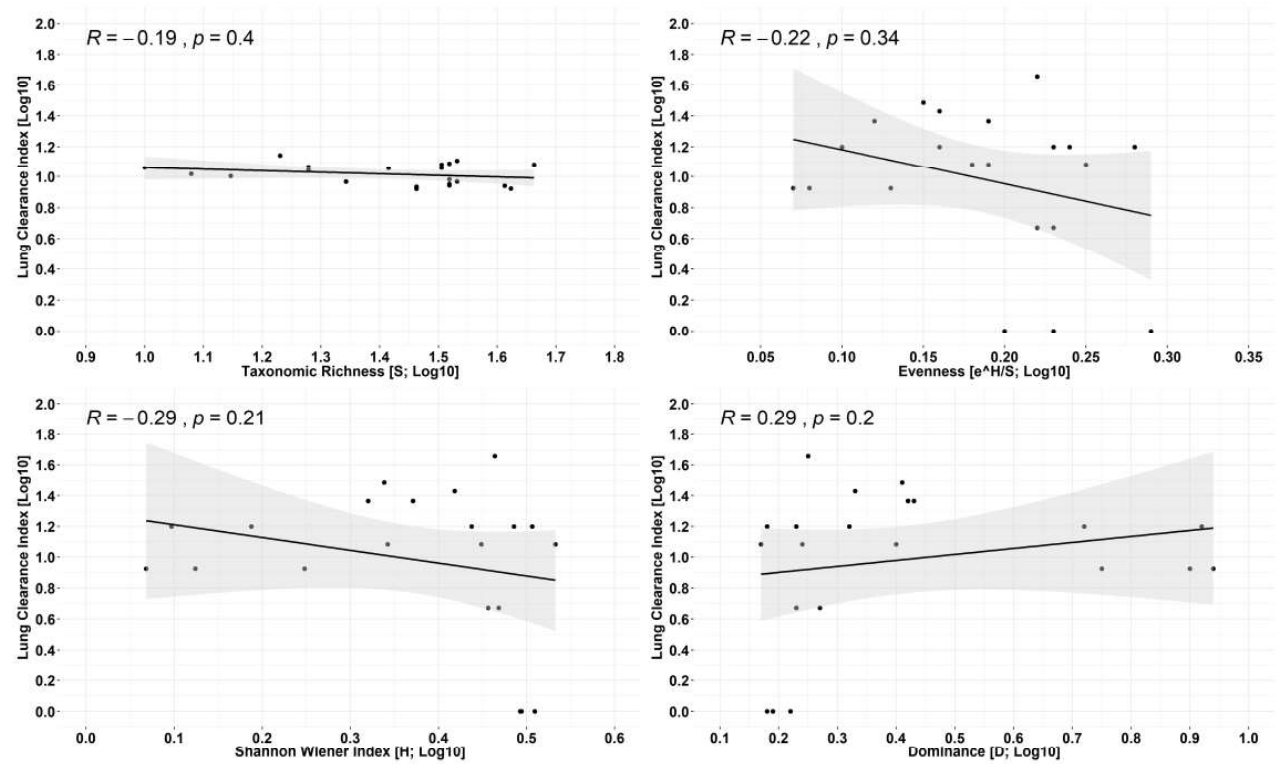

Supplementary Figure $1 \mathrm{~A}-\mathrm{K}$ : Scatterplot and univariate linear regression analysis clinical variables (vertical axis; dependent variable) and ecological measurements for microbial community composition (horizontal axis). Spearman's correlation coefficient $(R)$ indicates the strength of the association between the relevant variables and $p<0.05$ denotes statistical significance. The shaded area around the scatter-points denotes the $95 \% \mathrm{CI}$. 
Sample LCI02.001 LCI02.002 LCI02.003 LCI02.004 LCI02.008 LCI02.012 LCI02.015 LCI02.016

\begin{tabular}{|c|c|c|c|c|c|c|c|c|}
\hline Haemophilı & 0.94 & 5.44 & 2.83 & 94.67 & 86.72 & 53.56 & 0.17 & 0.06 \\
\hline Streptococı & 19.56 & 44.22 & 20.11 & 1.83 & 2.67 & 9.17 & 48.03 & 37.39 \\
\hline Veillonella & 10.22 & 8.94 & 27.78 & 0.94 & 0.56 & 2.28 & 8.95 & 6.33 \\
\hline Moraxella & 0 & 0 & 0 & 0 & 0 & 4.22 & 0 & \\
\hline Corynebact & 0.11 & 0.06 & 0.67 & 0 & 0.22 & 0 & 0 & \\
\hline Prevotella & 2.72 & 3 & 26.61 & 0.39 & 0.11 & 0.89 & 9.45 & 11.33 \\
\hline Pseudomor & 44.33 & 0 & 0 & 0.06 & 0 & 0.44 & 0 & \\
\hline Stenotroph & 0 & 0 & 0 & 0 & 0 & 0 & 0 & 0.11 \\
\hline f_Gemellac & 0.22 & 1.56 & 1.22 & 0.17 & 0.89 & 1.61 & 1.72 & 1.61 \\
\hline Neisseria & 0 & 5.5 & 0.89 & 0.11 & 1.44 & 14.17 & 0.06 & \\
\hline f_Carnobac & 1.67 & 4.33 & 1.67 & 0.17 & 0.33 & 1.94 & 0 & 0.11 \\
\hline Achromoba & 0 & 0 & 0 & 0 & 0 & 0 & 0 & \\
\hline Fusobacter & 0.83 & 1.89 & 2.89 & 0 & 0.94 & 0.78 & 9.34 & 8.1 \\
\hline Helcococcu & 0 & 0 & 0 & 0 & 0 & 0 & 0 & \\
\hline Parascardo' & 7.72 & 0 & 1.06 & 0 & 0.28 & 2.06 & 1.22 & 0.89 \\
\hline Leptotrichi: & 0.06 & 1.28 & 0.22 & 0.17 & 0.39 & 4.39 & 0.28 & 0.44 \\
\hline Lactobacillı & 0 & 0 & 2.89 & 0 & 0 & 0 & 8.28 & 10.11 \\
\hline f_Neisseria & 0 & 9.56 & 3 & 0 & 1.5 & 0 & 0.06 & 0.0 \\
\hline Oribacteriu & 2.56 & 1.22 & 0.22 & 0.22 & 0.33 & 0.5 & 0.17 & \\
\hline f_Clostridia & 0 & 0.33 & 1.89 & 0 & 0.33 & 0.11 & 3.56 & 5.0 \\
\hline Porphyrom & 0.06 & 1.28 & 1.06 & 0.39 & 0.72 & 2.22 & 0.67 & 0.8 \\
\hline Moryella & 1.78 & 1.72 & 0.22 & 0.17 & 0.06 & 0 & 0.89 & 1.39 \\
\hline Rothia & 0.11 & 0.11 & 0.06 & 0 & 0.06 & 0.22 & 0 & 8.44 \\
\hline Atopobium & 0.83 & 0.17 & 0.22 & 0.06 & 0.11 & 0.11 & 1.61 & 2.28 \\
\hline f_Alcaligen: & 0 & 0 & 0 & 0 & 0 & 0 & 0 & \\
\hline f_Lachnosp & 0.44 & 1.17 & 0 & 0 & 0.06 & 0.44 & 0 & 0. \\
\hline f_Paraprevı & 0.33 & 1.5 & 0.06 & 0.06 & 0.33 & 0 & 0 & \\
\hline Capnocytor & 0.06 & 0.33 & 0.89 & 0 & 0.28 & 0.33 & 0.78 & \\
\hline Megaspha€ & 2 & 0.5 & 0 & 0.11 & 0 & 0 & 0.06 & \\
\hline f_Xanthom & 0 & 0 & 0 & 0 & 0 & 0 & 0 & \\
\hline o_Streptop & 0 & 0 & 0.28 & 0 & 0 & 0 & 1.56 & 1.56 \\
\hline Selenomon & 1.06 & 0.28 & 0.17 & 0 & 0 & 0 & 0 & 0.1 \\
\hline Aggregatibi & 0.22 & 2.39 & 0 & 0 & 0 & 0 & 0 & \\
\hline Tannerella & 0 & 0.06 & 0.11 & 0 & 0.17 & 0 & 0.94 & 0.89 \\
\hline Actinomyc€ & 0.06 & 0.11 & 0.11 & 0 & 0.06 & 0 & 0.56 & $0.4<$ \\
\hline Lautropia & 0.17 & 0.72 & 0.11 & 0 & 0.33 & 0 & 0.22 & $0.2 \varepsilon$ \\
\hline Abiotrophic & 0 & 0.5 & 0 & 0 & 0.33 & 0 & 0.39 & $0.2 \varepsilon$ \\
\hline Catonella & 0.11 & 0.39 & 0 & 0 & 0 & 0 & 0 & \\
\hline f_mitochon & 0.67 & 0 & 0 & 0 & 0 & 0 & 0 & \\
\hline Granulicate & 0 & 0.17 & 0 & 0 & 0 & 0 & 0 & \\
\hline Dialister & 0.06 & 0.11 & 0.22 & 0 & 0 & 0.11 & 0.17 & 0.17 \\
\hline Kingella & 0 & 0.06 & 1.06 & 0 & 0 & 0 & 0.06 & 0.0 \\
\hline f_Gemellac & 0 & 0 & 0.06 & 0 & 0.06 & 0 & 0.11 & 0.0 \\
\hline Mogibacter & 0.11 & 0.17 & 0.06 & 0 & 0.06 & 0.11 & 0.06 & \\
\hline f_Pseudom & 0.83 & 0 & 0 & 0 & 0 & 0.06 & 0 & \\
\hline f_Lachnosp & 0 & 0 & 0 & 0 & 0 & 0 & 0 & \\
\hline f_Veillonell & 0.11 & 0.17 & 0.17 & 0 & 0 & 0 & 0.22 & \\
\hline Campyloba & 0 & 0 & 0.06 & 0 & 0 & 0.11 & 0 & 0.06 \\
\hline Actinobacil & 0 & 0.06 & 0 & 0.39 & 0 & 0 & 0 & \\
\hline f_Flavobact & 0 & 0.17 & 0 & 0 & 0 & 0.11 & 0 & 0.06 \\
\hline Peptostrep & 0 & 0.17 & 0 & 0 & 0 & 0 & 0 & \\
\hline
\end{tabular}




$\begin{array}{lrrrrrrrr}\text { Staphyloco } & 0 & 0 & 0.06 & 0.06 & 0 & 0 & 0.06 & 0.22 \\ \text { f_Neisseria } & 0 & 0 & 0 & 0 & 0.33 & 0 & 0 & 0 \\ \text { Scardovia } & 0 & 0 & 0 & 0 & 0 & 0 & 0 & 0.61 \\ \text { Treponema } & 0 & 0 & 0.44 & 0 & 0 & 0 & 0.06 & 0 \\ \text { f_Pasteurel } & 0 & 0 & 0.11 & 0 & 0 & 0 & 0 & 0 \\ \text { Slackia } & 0 & 0 & 0.06 & 0 & 0 & 0 & 0.33 & 0.11 \\ \text { O_Bacteroir } & 0 & 0 & 0 & 0 & 0.17 & 0 & 0 & 0 \\ \text { Mycoplasm } & 0 & 0.22 & 0 & 0 & 0 & 0 & 0 & 0 \\ \text { f_Actinomy } & 0 & 0 & 0 & 0 & 0 & 0 & 0 & 0 \\ \text { f_Propionit } & 0 & 0.06 & 0.06 & 0 & 0 & 0 & 0 & 0 \\ \text { f_Streptocc } & 0 & 0 & 0 & 0 & 0 & 0 & 0 & 0 \\ \text { Eikenella } & 0.06 & 0 & 0 & 0 & 0 & 0 & 0 & 0 \\ \text { P_Proteobi } & 0 & 0 & 0 & 0 & 0 & 0 & 0 & 0 \\ \text { f_Ruminoci } & 0 & 0 & 0 & 0.06 & 0 & 0 & 0 & 0 \\ \text { O_Clostridic } & 0 & 0 & 0.17 & 0 & 0 & 0 & 0 & 0 \\ \text { TG5 } & 0 & 0 & 0.06 & 0 & 0.06 & 0 & 0 & 0 \\ \text { Unclassifiec } & 0 & 0 & 0 & 0 & 0 & 0.06 & 0 & 0 \\ \text { Butyrivibric } & 0 & 0 & 0 & 0 & 0 & 0 & 0 & 0 \\ \text { Gemella } & 0 & 0 & 0 & 0 & 0 & 0 & 0 & 0 \\ \text { Peptoniphil } & 0 & 0 & 0.11 & 0 & 0 & 0 & 0 & 0 \\ \text { Sneathia } & 0 & 0 & 0 & 0 & 0 & 0 & 0 & 0 \\ \text { f_Enteroba } & 0 & 0 & 0.11 & 0 & 0 & 0 & 0 & 0 \\ \text { C_Acidobac } & 0 & 0 & 0 & 0 & 0 & 0 & 0 & 0 \\ \text { O_Gemellal } & 0 & 0 & 0 & 0 & 0 & 0 & 0 & 0 \\ \text { f_Streptocc } & 0 & 0.06 & 0 & 0 & 0 & 0 & 0 & 0 \\ \text { Peptococcu } & 0 & 0.06 & 0 & 0 & 0 & 0 & 0 & 0 \\ \text { f_Veillonell } & 0 & 0 & 0 & 0 & 0.06 & 0 & 0 & 0 \\ \text { f_Rhodospi } & 0 & 0 & 0 & 0 & 0 & 0 & 0 & 0 \\ \text { Desulfobult } & 0 & 0 & 0 & 0 & 0.06 & 0 & 0 & 0 \\ \text { Yersinia } & 0 & 0 & 0 & 0 & 0 & 0 & 0 & 0\end{array}$


LCI02.018 LCI02.026 LCI02.027 LCI02.030 LCI02.037 LCI02.039 LCI02.040 LCI02.044 LCI02.046

\begin{tabular}{|c|c|c|c|c|c|c|c|c|}
\hline 96 & 0.11 & 2.33 & 0.61 & 0 & 0 & 97.11 & 2.28 & 61.5 \\
\hline 1 & 29.94 & 35.44 & 38.72 & 9.44 & 25.67 & 1.89 & 27.22 & 20.83 \\
\hline 0.28 & 8.67 & 9.5 & 0.89 & 0.5 & 18.33 & 0.11 & 1.44 & 6.22 \\
\hline 0 & 0 & 0 & 0 & 0 & 0 & 0 & 50.17 & \\
\hline 0 & 0 & 0.28 & 0 & 55.39 & 0 & 0 & 0.06 & 0.11 \\
\hline 0.44 & 4.28 & 8.78 & 0.67 & 0.28 & 0.83 & 0.06 & 0.33 & 2.22 \\
\hline 0 & 35 & 0 & 0 & 0.06 & 0 & 0 & 0 & \\
\hline 0 & 0 & 0 & 49.44 & 0 & 0 & 0 & 0 & \\
\hline 0.17 & 7.33 & 5.22 & 0.61 & 0.56 & 2.11 & 0.28 & 2.89 & 2. \\
\hline 1.06 & 0 & 9.11 & 0 & 0 & 0 & 0 & 5.94 & 0.06 \\
\hline 0.17 & 6.83 & 11.39 & 0.22 & 0.56 & 2.33 & 0.33 & 0.78 & 1.2 \\
\hline 0 & 0 & 0 & 0 & 0 & 36.39 & 0 & 0 & \\
\hline 0 & 0.22 & 1.5 & 0.22 & 0.17 & 0.78 & 0 & 1.06 & 0.39 \\
\hline 0 & 0 & 0 & 0 & 32.06 & 0 & 0 & 0 & \\
\hline 0 & 0.67 & 1.61 & 0 & 0.33 & 1 & 0.06 & 0.11 & 0.56 \\
\hline 0 & 0 & 0.94 & 0.11 & 0 & 0.28 & 0.11 & 0.44 & 0.89 \\
\hline 0 & 0.06 & 0 & 0 & 0 & 0 & 0 & 0 & \\
\hline 0.06 & 0 & 0.22 & 0 & 0 & 0 & 0 & 1 & 0.11 \\
\hline 0.22 & 1.72 & 0.94 & 3 & 0 & 0.72 & 0 & 0 & 0.17 \\
\hline 0 & 0 & 0.28 & 0 & 0 & 0.22 & 0 & 0.67 & 0.22 \\
\hline 0 & 0.39 & 1.17 & 0 & 0 & 0 & 0 & 1.28 & \\
\hline 0.44 & 0.39 & 1.22 & 0 & 0.22 & 0.39 & 0 & 0.28 & 0.28 \\
\hline 0 & 0.06 & 0.06 & 0 & 0 & 0 & 0 & 0 & \\
\hline 0.06 & 0.28 & 1.22 & 0 & 0 & 0.17 & 0 & 0 & 0.22 \\
\hline 0 & 0 & 0 & 0 & 0 & 7.28 & 0 & 0 & \\
\hline 0 & 1 & 1.28 & 0.06 & 0.17 & 0.33 & 0 & 0 & 0.22 \\
\hline 0 & 0.5 & 0.22 & 0 & 0 & 0.11 & 0 & 0.61 & 0.06 \\
\hline 0 & 0.11 & 0.67 & 0 & 0 & 0.06 & 0 & 1.33 & 0.06 \\
\hline 0 & 0 & 0.61 & 0 & 0 & 0.17 & 0 & 0.06 & 0.44 \\
\hline 0 & 0 & 0 & 4.33 & 0 & 0 & 0 & 0 & \\
\hline 0 & 0 & 0.83 & 0 & 0 & 0 & 0 & 0 & \\
\hline 0 & 0 & 0.28 & 0.06 & 0.06 & 0.11 & 0 & 0 & 0.11 \\
\hline 0 & 0 & 0 & 0 & 0 & 0 & 0 & 0.67 & 0.1 \\
\hline 0 & 0 & 0.06 & 0 & 0 & 0.06 & 0 & 0.06 & 0 \\
\hline 0 & 0.11 & 0.33 & 0 & 0 & 0 & 0 & 0 & 0.61 \\
\hline 0 & 0 & 0.22 & 0 & 0 & 0 & 0 & 0.11 & 0.1 \\
\hline 0 & 0 & 0.61 & 0 & 0.11 & 0 & 0 & 0.06 & \\
\hline 0.06 & 0.33 & 0.17 & 0.11 & 0 & 0.39 & 0 & 0.06 & \\
\hline 0 & 0 & 0 & 0 & 0 & 1.33 & 0 & 0 & \\
\hline 0 & 0.67 & 0.28 & 0.67 & 0 & 0 & 0.06 & 0 & \\
\hline 0 & 0.17 & 0.06 & 0 & 0 & 0.06 & 0 & 0 & \\
\hline 0 & 0 & 0.11 & 0 & 0 & 0.06 & 0 & 0 & \\
\hline 0 & 0.11 & 0.44 & 0 & 0 & 0.06 & 0 & 0.17 & 0.1 \\
\hline 0.06 & 0 & 0.28 & 0 & 0 & 0.06 & 0 & 0 & 0.1 \\
\hline 0 & 0.5 & 0 & 0 & 0 & 0 & 0 & 0 & \\
\hline 0 & 0 & 1.06 & 0 & 0 & 0.11 & 0 & 0 & \\
\hline 0 & 0 & 0.11 & 0 & 0 & 0.11 & 0 & 0 & \\
\hline 0 & 0 & 0.39 & 0.06 & 0 & 0 & 0 & 0 & ( \\
\hline 0 & 0 & 0 & 0 & 0 & 0 & 0 & 0.56 & 0.1 \\
\hline 0 & 0.22 & 0.11 & 0.11 & 0 & 0 & 0 & 0.06 & \\
\hline 0 & 0.22 & 0 & 0 & 0 & 0.06 & 0 & 0.06 & 0.1 \\
\hline
\end{tabular}




$\begin{array}{rrrrrrrrr}0 & 0 & 0 & 0 & 0 & 0 & 0 & 0 & 0 \\ 0 & 0 & 0 & 0 & 0 & 0 & 0 & 0 & 0 \\ 0 & 0 & 0 & 0 & 0 & 0 & 0 & 0 & 0 \\ 0 & 0 & 0 & 0 & 0 & 0 & 0 & 0 & 0.06 \\ 0 & 0 & 0 & 0.11 & 0 & 0 & 0 & 0.17 & 0 \\ 0 & 0 & 0 & 0 & 0 & 0 & 0 & 0 & 0 \\ 0 & 0 & 0 & 0 & 0 & 0.17 & 0 & 0.06 & 0 \\ 0 & 0 & 0 & 0 & 0.06 & 0 & 0 & 0 & 0 \\ 0 & 0 & 0.11 & 0 & 0 & 0.06 & 0 & 0.06 & 0 \\ 0 & 0 & 0.11 & 0 & 0 & 0 & 0 & 0 & 0 \\ 0 & 0.06 & 0 & 0 & 0 & 0 & 0 & 0 & 0.06 \\ 0 & 0 & 0.17 & 0 & 0 & 0 & 0 & 0 & 0 \\ 0 & 0 & 0 & 0 & 0 & 0.22 & 0 & 0 & 0 \\ 0 & 0 & 0.11 & 0 & 0 & 0 & 0 & 0 & 0 \\ 0 & 0 & 0 & 0 & 0 & 0 & 0 & 0 & 0 \\ 0 & 0 & 0 & 0 & 0 & 0 & 0 & 0 & 0 \\ 0 & 0 & 0 & 0 & 0 & 0 & 0 & 0 & 0 \\ 0 & 0.06 & 0.06 & 0 & 0 & 0 & 0 & 0 & 0 \\ 0 & 0 & 0 & 0 & 0 & 0 & 0 & 0 & 0.11 \\ 0 & 0 & 0 & 0 & 0 & 0 & 0 & 0 & 0 \\ 0 & 0 & 0 & 0 & 0 & 0 & 0 & 0 & 0.11 \\ 0 & 0 & 0 & 0 & 0 & 0 & 0 & 0 & 0 \\ 0 & 0 & 0.06 & 0 & 0 & 0 & 0 & 0 & 0 \\ 0 & 0 & 0 & 0 & 0 & 0 & 0 & 0 & 0 \\ 0 & 0 & 0 & 0 & 0 & 0 & 0 & 0 & 0 \\ 0 & 0 & 0 & 0 & 0 & 0 & 0 & 0 & 0 \\ 0 & 0 & 0 & 0 & 0 & 0 & 0 & 0 & 0 \\ 0 & 0 & 0 & 0 & 0.06 & 0 & 0 & 0 & 0 \\ 0 & 0 & 0 & 0 & 0 & 0 & 0 & 0 & 0 \\ 0 & 0 & 0.06 & 0 & 0 & 0 & 0 & 0 & 0\end{array}$




\begin{tabular}{|c|c|c|c|}
\hline LCIO2.047 & LCI02.054 & LCI02.049 & LCI02.056 \\
\hline 0.39 & 83.94 & 3.28 & 0 \\
\hline 38.33 & 14.06 & 42.06 & 32.56 \\
\hline 3.22 & 0 & 6.61 & 20.11 \\
\hline 51.06 & 0 & 0 & 0 \\
\hline 0 & 0.11 & 16.33 & 11.83 \\
\hline 0.78 & 0 & 2.78 & 8.22 \\
\hline 0 & 0 & 0.06 & 0 \\
\hline 0 & 0 & 0 & 0 \\
\hline 2.44 & 0.44 & 1.83 & 8.83 \\
\hline 0.17 & 0.67 & 2.11 & 0 \\
\hline 1.39 & 0.44 & 1.11 & 4.11 \\
\hline 0 & 0 & 0 & 0 \\
\hline 0.28 & 0 & 1.72 & 3.06 \\
\hline 0 & 0 & 0 & 0 \\
\hline 0.56 & 0.06 & 0.89 & 4.44 \\
\hline 0.11 & 0 & 12.44 & 0.56 \\
\hline 0.11 & 0 & 0 & 0.33 \\
\hline 0 & 0 & 0 & 0 \\
\hline 0 & 0 & 0.78 & 1.33 \\
\hline 0.06 & 0 & 0.11 & 0.33 \\
\hline 0 & 0.11 & 0.17 & 0 \\
\hline 0.17 & 0.06 & 0.22 & 0 \\
\hline 0 & 0 & 0 & 0 \\
\hline 0 & 0 & 0.33 & 0.44 \\
\hline 0 & 0 & 0 & 0 \\
\hline 0.5 & 0 & 0.83 & 0.67 \\
\hline 0 & 0 & 2.67 & 0 \\
\hline 0.11 & 0 & 0.06 & 0.11 \\
\hline 0 & 0 & 0.78 & 0.17 \\
\hline 0 & 0 & 0 & 0 \\
\hline 0 & 0 & 0 & 0 \\
\hline 0 & 0 & 1.06 & 0.56 \\
\hline 0 & 0 & 0 & 0 \\
\hline 0 & 0 & 0.28 & 0 \\
\hline 0 & 0 & 0.17 & 0 \\
\hline 0 & 0.06 & 0.11 & 0 \\
\hline 0 & 0 & 0 & 0 \\
\hline 0 & 0 & 0.39 & 0.11 \\
\hline 0 & 0 & 0 & 0 \\
\hline 0 & 0 & 0 & 0 \\
\hline 0 & 0 & 0.06 & 0.44 \\
\hline 0.11 & 0 & 0 & 0.11 \\
\hline 0 & 0.06 & 0.06 & 0.28 \\
\hline 0.06 & 0 & 0.28 & 0.11 \\
\hline 0 & 0 & 0 & 0 \\
\hline 0 & 0 & 0 & 0 \\
\hline 0.06 & 0 & 0 & 0.17 \\
\hline 0 & 0 & 0 & 0.44 \\
\hline 0 & 0 & 0 & 0 \\
\hline 0 & 0 & 0.06 & 0 \\
\hline 0 & 0 & 0.06 & 0.17 \\
\hline
\end{tabular}




$\begin{array}{rrrr}0 & 0 & 0 & 0.33 \\ 0 & 0 & 0.28 & 0 \\ 0 & 0 & 0 & 0 \\ 0 & 0 & 0 & 0 \\ 0.06 & 0 & 0.06 & 0 \\ 0 & 0 & 0 & 0 \\ 0 & 0 & 0 & 0 \\ 0 & 0 & 0 & 0 \\ 0 & 0 & 0 & 0 \\ 0 & 0 & 0 & 0 \\ 0 & 0 & 0 & 0.11 \\ 0 & 0 & 0 & 0 \\ 0 & 0 & 0 & 0 \\ 0 & 0 & 0 & 0 \\ 0 & 0 & 0 & 0 \\ 0 & 0 & 0 & 0 \\ 0 & 0 & 0 & 0.06 \\ 0 & 0 & 0 & 0 \\ 0 & 0 & 0 & 0 \\ 0 & 0 & 0 & 0 \\ 0 & 0 & 0 & 0 \\ 0 & 0 & 0 & 0 \\ 0 & 0 & 0 & 0 \\ 0.06 & 0 & 0 & 0 \\ 0 & 0 & 0 & 0 \\ 0 & 0 & 0 & 0 \\ 0 & 0 & 0 & 0 \\ 0 & 0 & 0 & 0 \\ 0 & 0 & 0 & 0 \\ 0 & 0 & 0 & 0\end{array}$


STROBE Statement-Checklist of items that should be included in reports of cross-sectional studies

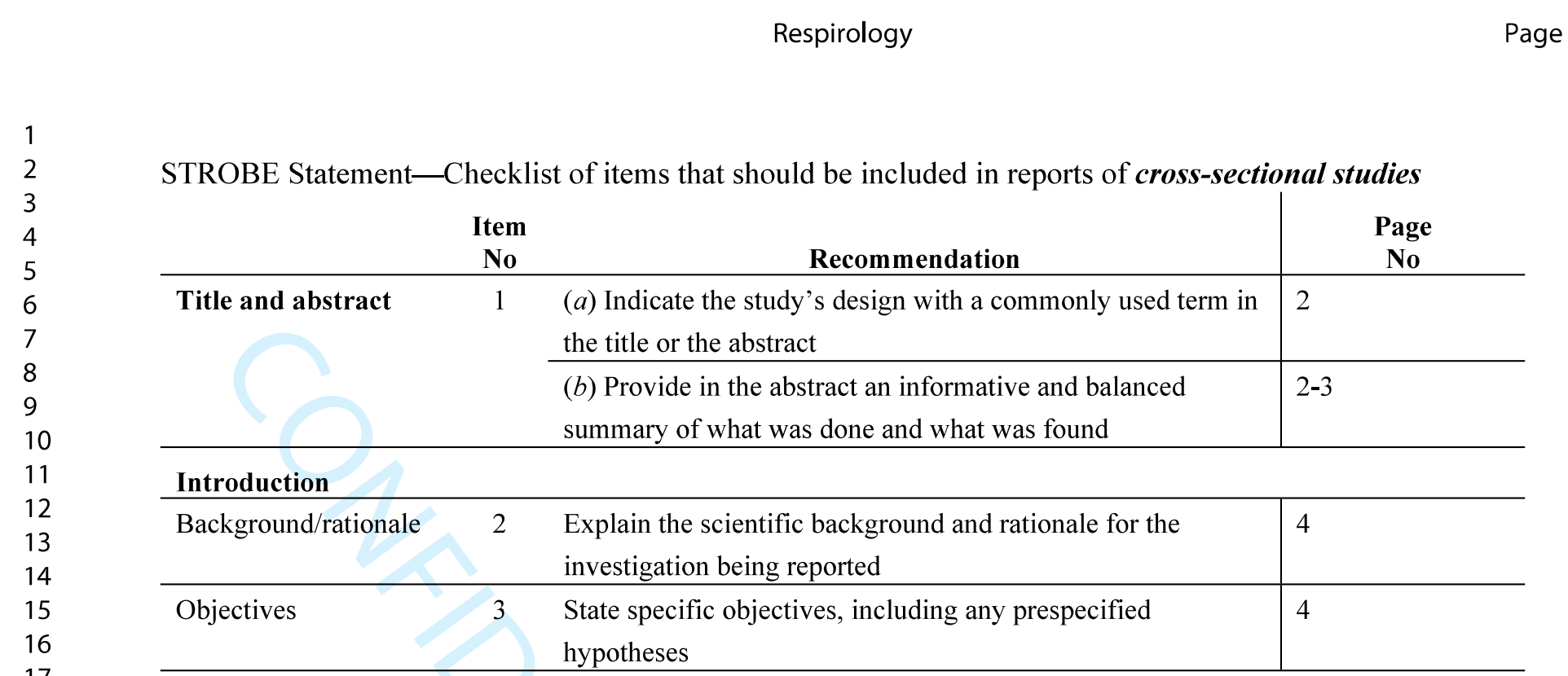

\section{Methods}

\begin{tabular}{|c|c|c|c|}
\hline Study design & 4 & Present key elements of study design early in the paper & 4 \\
\hline Setting & & $\begin{array}{l}\text { Describe the setting, locations, and relevant dates, including } \\
\text { periods of recruitment, exposure, follow-up, and data } \\
\text { collection }\end{array}$ & $4-5$ \\
\hline Participants & 6 & $\begin{array}{l}\text { (a) Give the eligibility criteria, and the sources and methods } \\
\text { of selection of participants }\end{array}$ & $\begin{array}{l}\text { 4-5 and } \\
\text { supplementary } \\
\text { appendix }\end{array}$ \\
\hline Variables & 7 & $\begin{array}{l}\text { Clearly define all outcomes, exposures, predictors, potential } \\
\text { confounders, and effect modifiers. Give diagnostic criteria, if } \\
\text { applicable }\end{array}$ & $4-7$ \\
\hline $\begin{array}{l}\text { Data sources/ } \\
\text { measurement }\end{array}$ & $8^{*}$ & $\begin{array}{l}\text { For each variable of interest, give sources of data and details } \\
\text { of methods of assessment (measurement). Describe } \\
\text { comparability of assessment methods if there is more than } \\
\text { one group }\end{array}$ & $4-7$ \\
\hline Bias & 9 & Describe any efforts to address potential sources of bias & - \\
\hline Study size & 10 & Explain how the study size was arrived at & 8 \\
\hline Quantitative variables & 11 & $\begin{array}{l}\text { Explain how quantitative variables were handled in the } \\
\text { analyses. If applicable, describe which groupings were } \\
\text { chosen and why }\end{array}$ & 7 \\
\hline \multirow[t]{5}{*}{ Statistical methods } & \multirow[t]{5}{*}{12} & $\begin{array}{l}\text { (a) Describe all statistical methods, including those used to } \\
\text { control for confounding }\end{array}$ & 7 \\
\hline & & $\begin{array}{l}\text { (b) Describe any methods used to examine subgroups and } \\
\text { interactions }\end{array}$ & - \\
\hline & & (c) Explain how missing data were addressed & - \\
\hline & & $\begin{array}{l}\text { (d) If applicable, describe analytical methods taking account } \\
\text { of sampling strategy }\end{array}$ & - \\
\hline & & $(\underline{e})$ Describe any sensitivity analyses & \\
\hline \multicolumn{4}{|l|}{ Results } \\
\hline \multirow[t]{3}{*}{ Participants } & \multirow[t]{3}{*}{$13^{*}$} & $\begin{array}{l}\text { (a) Report numbers of individuals at each stage of study-eg } \\
\text { numbers potentially eligible, examined for eligibility, } \\
\text { confirmed eligible, included in the study, completing follow- } \\
\text { up, and analysed }\end{array}$ & 8 \\
\hline & & (b) Give reasons for non-participation at each stage & - \\
\hline & & (c) Consider use of a flow diagram & - \\
\hline
\end{tabular}

\section{Results}

Participants

\begin{tabular}{|c|c|c|c|}
\hline Study design & 4 & Present key elements of study design early in the paper & 4 \\
\hline Setting & & $\begin{array}{l}\text { Describe the setting, locations, and relevant dates, including } \\
\text { periods of recruitment, exposure, follow-up, and data } \\
\text { collection }\end{array}$ & $4-5$ \\
\hline Participants & 6 & $\begin{array}{l}\text { (a) Give the eligibility criteria, and the sources and methods } \\
\text { of selection of participants }\end{array}$ & $\begin{array}{l}\text { 4-5 and } \\
\text { supplementary } \\
\text { appendix }\end{array}$ \\
\hline Variables & 7 & $\begin{array}{l}\text { Clearly define all outcomes, exposures, predictors, potential } \\
\text { confounders, and effect modifiers. Give diagnostic criteria, if } \\
\text { applicable }\end{array}$ & $4-7$ \\
\hline $\begin{array}{l}\text { Data sources/ } \\
\text { measurement }\end{array}$ & $8^{*}$ & $\begin{array}{l}\text { For each variable of interest, give sources of data and details } \\
\text { of methods of assessment (measurement). Describe } \\
\text { comparability of assessment methods if there is more than } \\
\text { one group }\end{array}$ & $4-7$ \\
\hline Bias & 9 & Describe any efforts to address potential sources of bias & - \\
\hline Study size & 10 & Explain how the study size was arrived at & 8 \\
\hline Quantitative variables & 11 & $\begin{array}{l}\text { Explain how quantitative variables were handled in the } \\
\text { analyses. If applicable, describe which groupings were } \\
\text { chosen and why }\end{array}$ & 7 \\
\hline \multirow[t]{5}{*}{ Statistical methods } & \multirow[t]{5}{*}{12} & $\begin{array}{l}\text { (a) Describe all statistical methods, including those used to } \\
\text { control for confounding }\end{array}$ & 7 \\
\hline & & $\begin{array}{l}\text { (b) Describe any methods used to examine subgroups and } \\
\text { interactions }\end{array}$ & - \\
\hline & & (c) Explain how missing data were addressed & - \\
\hline & & $\begin{array}{l}\text { (d) If applicable, describe analytical methods taking account } \\
\text { of sampling strategy }\end{array}$ & - \\
\hline & & $(\underline{e})$ Describe any sensitivity analyses & \\
\hline \multicolumn{4}{|l|}{ Results } \\
\hline \multirow[t]{3}{*}{ Participants } & \multirow[t]{3}{*}{$13^{*}$} & $\begin{array}{l}\text { (a) Report numbers of individuals at each stage of study-eg } \\
\text { numbers potentially eligible, examined for eligibility, } \\
\text { confirmed eligible, included in the study, completing follow- } \\
\text { up, and analysed }\end{array}$ & 8 \\
\hline & & (b) Give reasons for non-participation at each stage & - \\
\hline & & (c) Consider use of a flow diagram & - \\
\hline
\end{tabular}

(a) Indicate the study's design with a commonly used term in the title or the abstract

(b) Provide in the abstract an informative and balanced

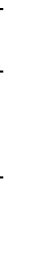


1

\begin{tabular}{|c|c|c|c|}
\hline \multirow[t]{2}{*}{ Descriptive data } & \multirow[t]{2}{*}{$14^{*}$} & $\begin{array}{l}\text { (a) Give characteristics of study participants (eg } \\
\text { demographic, clinical, social) and information on exposures } \\
\text { and potential confounders }\end{array}$ & 8 and Table 1 \\
\hline & & $\begin{array}{l}\text { (b) Indicate number of participants with missing data for each } \\
\text { variable of interest }\end{array}$ & - \\
\hline Outcome data & $15^{*}$ & Report numbers of outcome events or summary measures & - \\
\hline \multirow[t]{3}{*}{ Main results } & \multirow[t]{3}{*}{16} & $\begin{array}{l}\text { (a) Give unadjusted estimates and, if applicable, confounder- } \\
\text { adjusted estimates and their precision (eg, 95\% confidence } \\
\text { interval). Make clear which confounders were adjusted for } \\
\text { and why they were included }\end{array}$ & $\begin{array}{l}\text { Pages 8-10 } \\
\text { Figures A-K }\end{array}$ \\
\hline & & $\begin{array}{l}\text { (b) Report category boundaries when continuous variables } \\
\text { were categorized }\end{array}$ & - \\
\hline & & $\begin{array}{l}\text { (c) If relevant, consider translating estimates of relative risk } \\
\text { into absolute risk for a meaningful time period }\end{array}$ & - \\
\hline Other analyses & 17 & $\begin{array}{l}\text { Report other analyses done-eg analyses of subgroups and } \\
\text { interactions, and sensitivity analyses }\end{array}$ & Pages 8-10 \\
\hline \multicolumn{4}{|l|}{ Discussion } \\
\hline Key results & 18 & Summarise key results with reference to study objectives & 10 \\
\hline Limitations & 19 & $\begin{array}{l}\text { Discuss limitations of the study, taking into account sources } \\
\text { of potential bias or imprecision. Discuss both direction and } \\
\text { magnitude of any potential bias }\end{array}$ & 13 \\
\hline Interpretation & 20 & $\begin{array}{l}\text { Give a cautious overall interpretation of results considering } \\
\text { objectives, limitations, multiplicity of analyses, results from } \\
\text { similar studies, and other relevant evidence }\end{array}$ & 14 \\
\hline Generalisability & 21 & $\begin{array}{l}\text { Discuss the generalisability (external validity) of the study } \\
\text { results }\end{array}$ & $13-14$ \\
\hline \multicolumn{4}{|c|}{ Other information } \\
\hline Funding & 22 & $\begin{array}{l}\text { Give the source of funding and the role of the funders for the } \\
\text { present study and, if applicable, for the original study on } \\
\text { which the present article is based }\end{array}$ & 14 \\
\hline
\end{tabular}

* Give information separately for exposed and unexposed groups.

Note: An Explanation and Elaboration article discusses each checklist item and gives methodological background and published examples of transparent reporting. The STROBE checklist is best used in conjunction with this article (freely available on the Web sites of PLoS Medicine at http://www.plosmedicine.org/, Annals of Internal Medicine at http://www.annals.org/, and Epidemiology at http://www.epidem.com/). Information on the STROBE Initiative is available at www.strobe-statement.org. 


\section{Declaration of Competing Interests}

The corresponding author must complete and sign this form upon submission on behalf of all the co-authors. The completed form must be uploaded with the manuscript as Declaration of Competing Interests form at the time of submission.

First author: Katherine O'Neill

Article title: The composition of the airway bacterial community correlates with chest HRCT in adults with bronchiectasis

\section{Declaration of Competing Interests:}

A competing interest exists when professional judgement concerning a primary interest (such as patients' welfare or the validity of research) may be influenced by a secondary interest (such as financial gain or personal rivalry).

\section{Please answer all of the following questions}

1. Did a commercial entity at any stage:

If Yes, specify: Name of

a) fund the study in part or whole the company

b) contribute to the design of the study

Yes $\square$ No $\square$

c) undertake any analysis of the study

Yes $\square$ No $\square$

d) contribute to the writing of the manuscript

Yes $\square$ No $\square$

Yes $\square$ No $\square$

2. Have you or any of your co-authors accepted any funding or support from an organisation that may in any way gain or lose financially from the results of your study or the conclusions of your manuscript?

If Yes, specify authors' names and name of the organisation:

$$
\text { Yes } \square \text { No } \square
$$

3. Have you or any of your co-authors been employed by an organisation that may in any way gain or lose financially from the results of your study or the conclusions of your manuscript?

If Yes, specify authors' names and name of the organisation:

$$
\text { Yes } \square \text { No } \square
$$

4. Do you hold any stocks or shares in an organisation that may in any way gain or lose financially from the results of your study or the conclusions of your manuscript?

If Yes, specify authors' names and name of the organisation:

$$
\text { Yes } \square \text { No } \square
$$

5. Do you have any other competing interests? If so, please specify.

$$
\text { Yes } \square \text { No } \square
$$

\section{Clear All}

